OPEN ACCESS

Edited by:

Celio Geraldo Freire De Lima, Federal University of Rio de Janeiro,

Brazil

Reviewed by: Fernanda Ferreira Cruz, Federal University of Rio de Janeiro, Brazil Herbert Leonel de Matos Guedes, Federal University of Rio de Janeiro,

Brazil

Kelly Grace Magalhaes, University of Brasilia, Brazil

*Correspondence:

Maroun Khoury

mkhoury@uandes.cl

tThese authors have contributed equally to this work.

Specialty section:

This article was submitted to Microbial Immunology, a section of the journal

Frontiers in Immunology

Received: 12 December 2016 Accepted: 09 March 2017

Published: 30 March 2017

Citation:

Alcayaga-Miranda F, Cuenca J and Khoury M (2017) Antimicrobial Activity of Mesenchymal Stem Cells: Current Status and New Perspectives of Antimicrobial Peptide-Based

Therapies.

Front. Immunol. 8:339. doi: 10.3389/fimmu.2017.00339

\section{Antimicrobial Activity of Mesenchymal Stem Cells: Current Status and New Perspectives of Antimicrobial Peptide-Based Therapies}

\author{
Francisca Alcayaga-Miranda ${ }^{1,2+}$, Jimena Cuenca ${ }^{1,2+}$ and Maroun Khoury ${ }^{1,2,3 *}$ \\ ${ }^{1}$ Laboratory of Nano-Regenerative Medicine, Faculty of Medicine, Universidad de Los Andes, Santiago, Chile, \\ ${ }^{2}$ Cells for Cells, Santiago, Chile, ${ }^{3}$ Consorcio Regenero, Chilean Consortium for Regenerative Medicine, Santiago, Chile
}

While mesenchymal stem cells (MSCs)-based therapy appears to be promising, there are concerns regarding possible side effects related to the unwanted suppression of antimicrobial immunity leading to an increased risk of infection. Conversely, recent data show that MSCs exert strong antimicrobial effects through indirect and direct mechanisms, partially mediated by the secretion of antimicrobial peptides and proteins (AMPs). In fact, MSCs have been reported to increase bacterial clearance in preclinical models of sepsis, acute respiratory distress syndrome, and cystic fibrosis-related infections. This article reviews the current evidence regarding the direct antimicrobial effector function of MSCs, focusing mainly on the role of MSCs-derived AMPs. The strategies that might modulate the expression and secretion of these AMPs, leading to enhanced antimicrobial effect, are highlighted. Furthermore, studies evaluating the presence of AMPs in the cargo of extracellular vesicles (EVs) are underlined as perspective opportunities to develop new drug delivery tools. The antimicrobial potential of MSCs-derived EVs can also be heightened through cell conditioning and/or drug loading. Finally, improving the pharmacokinetics and delivery, in addition to deciphering the multi-target drug status of AMPs, should synergistically lead to key advances against infections caused by drugresistant strains.

Keywords: mesenchymal stromal cells, mesenchymal stem cells, antimicrobial effect, antibacterial property, AMPs

\section{INTRODUCTION}

Human mesenchymal stem or stromal cells (MSCs) are self-renewing multipotent cells with great potential for regenerative medicine and tissue engineering. MSCs are located within the stroma of the bone marrow (BMSCs) and other organs, including adipose tissue (AT-MSCs), dental pulp (DP-MSCs), postnatal tissues, such as umbilical cord (UC-MSCs) and placenta (PL-MSCs), or menstrual fluid (MenSCs), with each MSCs-population displaying individual differentiation potential and phenotype (1-7). According to the Mesenchymal and Tissue Stem Cell Committee of the International Society for Cellular Therapy (ISCT, www.celltherapysociety.org/), the minimal criteria 
for defining human MSCs are (a) adherence to plastic surface; (b) specific surface antigen expression (Positive expression of CD105, CD73, and CD90, and lack expression of CD45, CD34, CD14 or CD11b, CD79a or CD19, and HLA-DR); and (c) multipotent differentiation potential to osteoblast, adipocytes, and chondroblasts using standard in vitro tissue culture-differentiating conditions (8). Their versatility, homing preference for injured tissue, their immune privileged status, and the lower risk of tumorigenesis render them an interesting instrument in cell-based therapy (7). Due to their differentiation plasticity, immunomodulatory properties, angiogenic modulation, and paracrine support (9-13), MSCs have been investigated in a wide spectrum of disease indications, which is evidenced in the $\sim 500$ trials enrolled in the ClinicalTrials.gov database of the NIH (http://www.clinicaltrials. gov/, queried in December 2016).

Despite the demonstrated biologic effect and regenerative properties of MSCs in vitro and in vivo, the exact knowledge about their mechanism of action is still unknown. However, it is now widely accepted that MSCs exert their effect by paracrine stimulations through the release of small molecules as growth factors, cytokines, and chemokines $(14,15)$. Although initial clinical results of MSCs-based therapy showed promising outcomes, there are significant concerns that application of MSCs may inadvertently suppress antimicrobial immunity with an increased risk of infection (16). On the other hand, current data suggest that MSCs exert strong antimicrobial effects through indirect and direct mechanisms (16-26). Indirectly, across their role in the host immune response against pathogens, especially in the dynamic coordination of the pro- and anti-inflammatory elements of the immune system $(22,27-29)$ or increasing the activity of phagocytes $(18,21,25,30,31)$; and directly, by the secretion of antimicrobial peptides and proteins (AMPs) (19, $20,23,24,26)$, and also by the expression of molecules such as indoleamine 2,3-dioxygenase (IDO) (16) and interleukin (IL)-17 (32). In fact, MSCs have been reportedly responsible of the bacterial clearance in preclinical models of sepsis $(17-20,22,25)$, acute respiratory distress syndrome (ARDS) $(21,26)$, and cystic fibrosis infection (23).

AMPs or host-defense peptides and proteins are an abundant and diverse group of endogenous molecules that are produced as a first line of defense by all multicellular organisms which have a broad spectrum of antimicrobial and immunomodulatory activities (33). These molecules have selective activity against a wide range of organisms including bacteria, yeasts, fungi, viruses, and even cancer cells (34). So far, MSCs have been found to constitutively express four AMPs: cathelicidin LL-37 (19, 23), human $\beta$-defensin-2 (hBD-2) (24), hepcidin (20), and lipocalin-2 (Lcn2) (26), which can be further modulated during infection and inflammation. In fact, it has been demonstrated that, in MSCs, a bacterial preconditioning induces an upregulation of LL-37, hBD-2, and hepcidin $(19,20,24)$, while their preconditioning with inflammatory stimuli evoke increasing levels of LL-37 and Lcn2 $(23,26)$. In different preclinical models, MSCs-derived AMPs have demonstrated to be part of the bacterial clearance effect observed with MSCs treatment, revealing that MSCs can directly enhance the innate immune response to bacterial infection $(19,20,23,24,26)$.
In this review, we summarize the current evidence regarding the direct antimicrobial effector function of MSCs, focusing mainly in the role of the MSCs-derived AMPs. The different strategies that could modulate the expression and secretion of these AMPs and enhance their antimicrobial effect are emphasized. We also underline the presence of AMPs in the cargo of extracellular vesicles (EVs) present in body fluids and secreted by different type of cells including activated MSCs.

\section{ANTIMICROBIAL PEPTIDES}

Antimicrobial peptides are evolutionary conserved gene-encoded small effector molecules (10-150aa) found in organisms from procaryotes to humans $(34,35)$. Some of these antimicrobial peptides are present constitutively, while others may be induced in response to infection or inflammatory conditions. AMPs display different mechanisms of action (MoA) leading to the elimination of microorganisms, some of which are also dependent on external factors, such as $\mathrm{pH}$, peptide abundance, and salt concentration $(33,36)$.

Human AMPs interact with different molecular targets either on the cell surface or within the cells. AMPs-mediated cell killing occurs by disrupting membrane integrity, by inhibiting protein, DNA or RNA synthesis, and by interacting with certain intracellular targets (33). In general, AMPs are only effective against one class of pathogen (e.g., bacteria or fungi); however, some AMPs display MoA against several types of microorganisms (37). Importantly, in some specific cases, AMPs can be active against pathogens that are resistant to conventional antibiotics (ABs) as multidrug-resistant bacteria. These advantageous features make AMPs good candidates for drug development, although their clinical and commercial development still needs to overcome challenges, such as route of administration, potential toxicity, stability, and high cost of peptide production (38).

AMPs are also called "host defense peptides," a terminology that emphasizes their immunomodulatory functions (39). These functions are diverse, specific to the type of AMPs, and include different cytokines and growth factor-like effects that are relevant to both innate and adaptive immune responses (34). Hence, AMPs can also help to resolve inflammation or infections through indirect effects, which act in synergy with the direct antimicrobial activity.

To date, more than 2,700 AMPs of different sources have been registered in the Antimicrobial Peptide Database (APD, http:// aps.unmc.edu/AP/main.php; last updated on sixth January 2017) including 115 that are human host defense peptides. In Table 1, we have summarized some representative human AMPs and their characteristics in terms of source, activity, 3D structure, and length.

Besides their antimicrobial activities, AMPs also show indirect biological effects that may help to eradicate infection (66). In this context, it has been described that AMPs secreted by epithelial cells present a battery of biological features including chemokine and anti-endotoxin activities as well as protease inhibition, bacterial opsonization, and angiogenic properties (66). Specifically, cathelicidins are chemotactic for monocytes, neutrophils, and lymphocytes (67) and it has been demonstrated that LL-37 
TABLE 1 | Human selected antimicrobial peptides.

\begin{tabular}{|c|c|c|c|c|c|c|c|}
\hline \multirow[t]{2}{*}{ Name } & \multirow[t]{2}{*}{ Source } & \multirow[t]{2}{*}{ Activity } & \multicolumn{3}{|c|}{$\begin{array}{l}\text { 3D } \\
\text { structure }^{a} \\
\text { (35) }\end{array}$} & \multirow[t]{2}{*}{$\begin{array}{l}\text { Length } \\
\text { (aa) }\end{array}$} & \multirow[t]{2}{*}{ Reference } \\
\hline & & & $\alpha$ & $\boldsymbol{\beta}$ & $\alpha \boldsymbol{\beta}$ & & \\
\hline Cathelicidin LL-37 & $\begin{array}{l}\text { Neutrophils, skin monocytes, lymphocytes, MCS, sweat, airway surface liquid, } \\
\text { saliva }\end{array}$ & $G, V, F, P, C$ & $\sqrt{ }$ & & & 37 & $(40)$ \\
\hline Dermcidin & Skin, sweat & $\mathrm{G}, \mathrm{F}$ & $\sqrt{ }$ & & & 47 & $(41)$ \\
\hline Granulysin & Cytolitic T and NK cells & $G, F, P, C$ & $\sqrt{ }$ & & & 74 & $(42)$ \\
\hline Histatin 5 & Saliva & $\mathrm{V}, \mathrm{F}$ & $\sqrt{ }$ & & & 24 & $(43)$ \\
\hline Lactoferricin & Human milk, tears, saliva, bronchial mucus, and seminal plasma & $G, V, F, P$ & $\sqrt{ }$ & & & 49 & $(44)$ \\
\hline Lysozyme & Saliva, tears, intestine & $G, F$ & $\sqrt{ }$ & & & 130 & $(45)$ \\
\hline Psoriasin/S100A7 & Skin, salivary gland, breast & G- & $\sqrt{ }$ & & & 101 & $(46)$ \\
\hline$\alpha$-Defensin HNP-1 & Neutrophils, bone marrow & G, V, F, P, C & & $\sqrt{ }$ & & 30 & $(47)$ \\
\hline$\alpha$-Defensin HNP-2 & Neutrophils, bone marrow & $\mathrm{G}, \mathrm{V}, \mathrm{F}, \mathrm{C}$ & & $\sqrt{ }$ & & 29 & $(47)$ \\
\hline$\alpha$-Defensin HNP-3 & Neutrophils, bone marrow & $\mathrm{G}, \mathrm{V}, \mathrm{F}, \mathrm{C}$ & & $\sqrt{ }$ & & 30 & $(47)$ \\
\hline$\alpha$-Defensin HNP-4 & Neutrophils & $G, V, F$ & & $\sqrt{ }$ & & 33 & $(48)$ \\
\hline$\alpha$-Defensin HD-5 & Paneth cells, intestine, female reproductive system & $\mathrm{G}, \mathrm{V}, \mathrm{F}$ & & $\sqrt{ }$ & & 32 & (49) \\
\hline$\alpha$-Defensin HD-6 & Paneth cells, intestine & $\mathrm{G}, \mathrm{V}, \mathrm{F}$ & & $\sqrt{ }$ & & 32 & $(50)$ \\
\hline Hepcidin 20 & Plasma, urine, liver & G, F & & $\sqrt{ }$ & & 20 & (51) \\
\hline Hepcidin 25 (LEAP-1) & $\begin{array}{l}\text { Plasma, urine/liver heart, kidney, adipose tissue, pancreas and hematopoietic cells, } \\
\text { MSCs, myeloid cells (monocytes, macrophages, neutrophils) }\end{array}$ & $G, F$ & & $\sqrt{ }$ & & 25 & $(51)$ \\
\hline $\begin{array}{l}\text { Secretory leukoprotease } \\
\text { inhibitor (SLPI) }\end{array}$ & Tears, saliva, airway, gastrointestines, genital tracts & $\mathrm{G}, \mathrm{V}, \mathrm{F}$ & & $\sqrt{ }$ & & 102 & $(52)$ \\
\hline RNase 5 angiogenin & Liver, skin, intestine & $\mathrm{G}+, \mathrm{F}$ & & & $\sqrt{ }$ & 125 & (53) \\
\hline Chemokine CCL1 & T cells & G & & & $\sqrt{ }$ & 73 & $(54)$ \\
\hline Chemokine CCL8 & Fibroblasts, endothelial cells & G- & & & $\sqrt{ }$ & 75 & $(54)$ \\
\hline Chemokine CCL13 & Epithelial cells, mononuclear cells & G- & & & $\sqrt{ }$ & 75 & $(54)$ \\
\hline Chemokine CCL2O & Skin, B cells, myeloid dendritic cell, memory T cell & $\mathrm{G}, \mathrm{F}, \mathrm{P}$ & & & $\sqrt{ }$ & 69 & $(54,55)$ \\
\hline Chemokine CCL27 & Memory T cell & F & & & $\sqrt{ }$ & 56 & (56) \\
\hline Chemokine CXCL1 & Macrophages, neutrophils, epithelial cells & G & & & $\sqrt{ }$ & 73 & $(54)$ \\
\hline Chemokine CXCL10 & Monocytes, endothelial cells, fibroblasts & $G, F, P$ & & & $\sqrt{ }$ & 77 & $(57)$ \\
\hline$\beta$-Defensin hBD-1 & Kidney, skin, salivary glands & $G, F, C$ & & & $\sqrt{ }$ & 36 & $(58)$ \\
\hline$\beta$-Defensin hBD-2 & Skin, lung, epithelia, uterus, salivary glands & $\mathrm{G}, \mathrm{V}, \mathrm{F}$ & & & $\sqrt{ }$ & 41 & (58) \\
\hline$\beta$-Defensin hBD-3 & Skin, salivary glands & $\mathrm{G}, \mathrm{V}, \mathrm{F}$ & & & $\sqrt{ }$ & 45 & $(58)$ \\
\hline $\begin{array}{l}\text { Neutrophil gelatinase- } \\
\text { associated lipocalin (NGAL, } \\
\text { Lcn2) }\end{array}$ & $\begin{array}{l}\text { Bone marrow, uterus, prostate, salivary gland, stomach, appendix, colon, } \\
\text { trachea, lung, small intestine, pancreas, kidney and prostate. MSCs, neutrophils, } \\
\text { macrophages, and dendritic cells }\end{array}$ & G & & & $\sqrt{ }$ & 178 & $(59-63)$ \\
\hline Reglll $\alpha$ & Intestine & $\mathrm{G}+$ & & & $\sqrt{ }$ & 149 & $(64)$ \\
\hline RNase 7 & Urinary tract, respiratory tract, skin & $G, F$ & & & $\sqrt{ }$ & 128 & $(65)$ \\
\hline
\end{tabular}

${ }^{a}$ Data from the APD (http://aps.unmc.edu/AP/database/query_input.php). Antimicrobial activities are annotated as G, bacteria; G+, Gram-positive bacteria only; G-, Gram-negative bacteria only; F, fungi; $P$, parasites; $V$, viruses; $C$, cancer cells.

binds and neutralizes lipopolisacharide (LPS), protecting against endotoxic shock in a mouse model of septicemia (68). Likewise, $\beta$-defensins are chemotactic for macrophages, neutrophils, and mast cells, possibly by binding to CCR6 (69). As for hepcidin (70, $71)$ and $\operatorname{Lcn} 2(34,72)$ they are involved in pathways regulating the availability of iron, a vital element for bacterial growth.

Recently, MSCs have also been described to possess antimicrobial activity, which would be given by antimicrobial peptides or proteins of members of the cathelicidins $(19,23)$, defensins (24), hepcidin (20), or lipocalin families (26).

Cathelicidins, defensins, and hepcidin are synthesized as pre-pro peptides that are cleaved to release mature AMPs that interact with negatively charged bacterial membrane surface (73). Lipocalins (Lcns) are characterized by their ability to bind small hydrophobic molecules, their binding to specific cell-surface receptors, and their formation of macromolecular complexes (74).

\section{Cathelicidins}

To date, only one cathelicidin gene (CAMP) has been described in mice and human, inducing a protein named CRAMP and LL-37, respectively (75). LL-37 exhibits a broad spectrum of antimicrobial activity, several immunomodulatory effects, anticancer activities, and also chemotactic and pro-angiogenic properties $(35,40)$. It has been detected in several types of cells, tissues, and fluids, and along with other AMPs, such as $\beta$-defensins, plays a central role in mucosal defense (76). An increased or decreased expression of LL-37 has been identified in several diseases, observing elevated levels in inflammatory pathologies like systemic lupus erythematosus and pulmonary diseases (77-79). In contrast, low production of LL-37 is associated with asthma and skin disorders (80-82).

The expression of LL-37 is driven by several stimuli such as inflammatory mediators and microbial structures, and varies depending on cell type (83) (Table 2). Vitamin D3 appears to be 
TABLE 2 | Factors that can modulate LL-37, hBD-2, hepcidin, and Lcn2 expression.

\begin{tabular}{|c|c|c|c|c|c|c|c|}
\hline \multicolumn{2}{|l|}{ LL-37 } & \multicolumn{2}{|l|}{ hBD-2 } & \multicolumn{2}{|l|}{ Hepcidin } & \multicolumn{2}{|l|}{ Lcn2 } \\
\hline Factor upregulation & Reference & Factor upregulation & Reference & Factor upregulation & Reference & Factor upregulation & Reference \\
\hline IL-17A (in synergy with vitamin D3) & (84) & LPS & (85) & IL-6, IL-1 $\alpha$, IL-22, oncostatin M & $(86,87)$ & Anemia & (88) \\
\hline $\mathrm{TNF} \alpha, \mathrm{IFN} \gamma$ & $(89,90)$ & $\mathrm{IL}-1, \mathrm{TNF} \alpha$ & (91) & Activin B & (92) & LPS & (62) \\
\hline Injury, wounding, UVB irradiation & $(89,93)$ & TLR-2 & $(94,95)$ & Liver metabolic activities & (96) & $\begin{array}{l}\text { IL-1 } \alpha \text { and } \beta, \text { IL-4, IL-17, IL-22, IL-9, } \\
\text { TNF } \alpha\end{array}$ & $(97-104)$ \\
\hline Sodium butyrate, phenyl butyrate & $(105-107)$ & IL-17 & (76) & Oxygenases & (96) & IGF-1, TGF $\alpha$ & $(108)$ \\
\hline $\begin{array}{l}\text { TLR agonists, lithocholic acid, } \\
\text { vitamin D receptor agonists }\end{array}$ & $(89,109-112)$ & AP-1, MEF & $(94,113)$ & $\begin{array}{l}\text { Small molecule activators of Stat/Smad pathways } \\
\text { (genistein) }\end{array}$ & (114) & $\begin{array}{l}\text { Serum, growth factors, phorbol esters, } \\
\text { Glucocorticoids (dexamethasone) }\end{array}$ & $(115,116)$ \\
\hline ER stress & (93) & Neutrophil elastase & $(117)$ & BMP6 & (118) & 3-cis retinoic acid (isotretinoin); 4-HPR & $(119,120)$ \\
\hline Short-chain fatty acids, $Z^{2+}$, lactose & $(121-123)$ & Calcium & (124) & TMPRSS6 siRNA or ASOs & (125) & MK886, nordihydroguaiaretic acid & $(126,127)$ \\
\hline$B C G$ & (128) & UV light & (89) & HFE, TfR2 & (96) & $\begin{array}{l}\text { COX-2 inhibitors, celecoxib-derived } \\
\text { PDK1 inhibitors }\end{array}$ & (126) \\
\hline Factor downregulation & Reference & $\begin{array}{l}\text { Factor } \\
\text { downregulation }\end{array}$ & Reference & Factor downregulation & Reference & Factor downregulation & Reference \\
\hline $\begin{array}{l}\text { Bacterial exotoxins, Shigella, } \\
\text { Neisseria infection }\end{array}$ & $(107,129-131)$ & $\begin{array}{l}\text { Glucocorticoids } \\
\text { (dexamethasone) }\end{array}$ & $(76,124)$ & $\begin{array}{l}\text { Oxidative stress (ROS); hypoxia; heparin; anti- } \\
\text { inflammatories (anti-IL-6/LL-6R (siltuximab)/ } \\
\text { (tocilizumab), anti-TNF } \alpha, A G 490 \text { ) }\end{array}$ & $(96,132-136)$ & L-Glutamine, $N$-acetylcysteine & $(137,138)$ \\
\hline 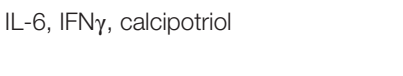 & $(89,139)$ & Calcium quelator & (124) & $\begin{array}{l}\text { Matriptase2, s-HJV-Fc, GDF15, erythropoiesis- } \\
\text { stimulating agents }\end{array}$ & $\begin{array}{l}(96,132 \\
140)\end{array}$ & Paricalcitol & $(141)$ \\
\hline $\begin{array}{l}\text { Psychological stress; transmigration } \\
\text { across activated endothelium }\end{array}$ & $(142,143)$ & $\begin{array}{l}\text { Inhibitors of NF-kB } \\
\text { and AP-1 }\end{array}$ & (124) & $\begin{array}{l}\text { Small molecule inhibitors of the BMPR type I kinase } \\
\text { (LDN-193189); anti-BMP6 antibody; HJV ASOs, } \\
\text { hepcidin ASOs or siRNA, TfR2 siRNA; PpYLKTK } \\
\text { (disruptor of STAT3 dimerization) }\end{array}$ & $\begin{array}{l}(118,140 \\
183-187)\end{array}$ & EGF, miR-138 & $(144,145)$ \\
\hline
\end{tabular}

IL-17A, interleukin-17; TNF, tumor necrosis alpha; IFN, interferon; UV, ultraviolet light; IL-6, interleukin 6; LPS, lipopolysaccharide; IL-1, interleukin 1; IL-22, interleukin 22; TLR, toll-like receptor; BCG, Mycobacterium bovis bacillus Calmette-Guérin; AP-1, activator protein 1; MEF, myeloid elf-1-like factor; NF-kB, nuclear factor-kB; BMP6, bone morphogenetic protein 6; TMPRSS6, transmembrane protease serine 6; siRNA, small interfering RNA; HFE, human hemochromatosis protein; TfR2, transferrin receptor 2; s-HJV-Fc, soluble form of hemojuvelin; GDF15, growth differentiation factor 15; BMPR, bone morphogenetic protein receptor; STAT3, signal transducer and activator of transcription 3; ASOs, antisense oligonucleotides; HJV, hemojuvelin; EGF, epidermal growth factor; COX-2, cyclooxygenase-2; PDK1, phosphoinositide-dependent kinase 1; 4-HPR; N-(4-hydroxyphenyl)retinamide; ER, endoplasmic reticulum; miR-138, microRNA-138; IGF-1, insulin like growth factor-1; TGFo, transforming growth factor alpha. 
the major regulator of LL-37 expression in humans as the CAMP gene encoding LL-37 contains three VDREs (Vitamin D response element) on its promoter. Upregulating the expression of natural LL-37 or developing synthetic mimics might represent a potent new therapeutic option that needs to be carefully evaluated.

\section{Defensins}

The defensin family of AMPs can be classified as $\alpha$-defensins, $\beta$-defensins, or $\theta$-defensins depending on their cellular origin, gene structure, and connectivity of the cysteine residues in their sequence (75). Defensins play important roles in innate and adaptive immunity against microbial and viral infections and also participate in wound repair, cytokines and chemokine expression, production of histamine, and enhancement of antibody responses (58).

$\beta$-Defensins, hBD-1, hBD-2, and hBD-3 are the mainly functional peptides in humans (35) expressed by many epithelial cells, granulocytes, and MSCs (24). Except for hBD-1, their expression is inducible (75), hBD-2 and hBD-3 are induced by pro-inflammatory stimuli or microorganisms $(91,146)$. hBD-1 and 2 are microbicidal predominantly against Gram-negative bacteria, while hBD-3 is a broad-spectrum antimicrobial peptide. Given their significant antimicrobial and antiviral activity, modulating endogenous defensin production through the use of specific regulatory stimuli makes defensins promising candidates for therapy (Table 2). Direct administration to sites such as the skin or cervico-vaginal mucosa for treatment of wounds or infection is of interest, particularly in conditions where antimicrobial peptide generation is reduced (76).

\section{Hepcidin}

Hepcidin is a natural human host defense peptide, originally found in urine and plasma $(147,148)$ which is produced mainly by hepatocytes but also by other cells including MSCs and myeloid leukocytes (71).

Hepcidin is known to act as an iron regulatory hormone, as well as it exerts a broad spectrum of antimicrobial activity against fungal species and clinical relevant bacteria such as Escherichia coli, S. epidermidis, S. aureus, and group B streptococci; however, the role as an antimicrobial peptide remains to be further unraveled for most type of infections $(51,147)$. Both peptides forms of hepcidin (hep-20 and hep-25) exhibit antimicrobial properties (147); however, hep-20 is not involved in the regulation of iron use (149).

The expression of hepatocyte hepcidin is regulated by iron status through the BMP-SMAD pathway and by inflammation, where the binding of inflammatory cytokines like IL-6 triggers the JAK-signal transducer and activator of transcription 3 (STAT3) signaling pathway $(150,151)$. An hepcidin-mediated hypoferremia could functions as a host defense mechanism that evolved to restrict iron availability and slow the pathogen growth (70, 71). The enhancement of bactericidal activity at low $\mathrm{pH}$ renders these peptides interesting for the development of drugs specifically designed, for example, for bacterial and/or fungal infections occurring in body areas with acidic $\mathrm{pH}(51,152)$. Thus, modulation of the hepcidin pathway (Table 2) has become an interesting target for new therapeutic strategies (140).

\section{Lipocalins}

Lipocalins are a family of small soluble proteins, which are often secreted (88). Lcns functions as transporters binding small organic molecules that have been associated with many biological processes: the immune response, cell growth, proliferation and metabolism, synthesis of prostaglandins, and iron transportation (153). Lcn2 appears to have an important role in innate antimicrobial defense mechanism (154) and in contrast with other AMPs, it exerts an indirect function against pathogens.

Originally, Lcn2 was identified as a component of neutrophil granules; however, it was later shown to be also expressed in various cells such as macrophages, adipocytes, MSCs, and epithelial cells in response to inflammatory conditions $(26,115$, 153, 155) (Table 2). The antimicrobial role is given by its ability to sequesters bacterial iron chelators, called siderophores, that consequently prevent the iron transfer to bacteria and arrested their growth (bacteriostatic effect) $(34,72)$. This function was demonstrated using mice genetically lacking $\operatorname{Lcn} 2$ that showed a marked increase in mortality in an E. coli-induced sepsis model $(155,156)$. Other studies revealed that Lcn2 also binds other types of siderophores, such as bacillibactin (B. anthracis) (157) and carboxy-mycobactin (mycobacteria) (158). Lcn2 is one of the most commonly studied novel biomarkers (159) and has emerged as a promising biomarker for different pulmonary diseases (97), kidney injury (160-163), liver failure (164), and tumorigenesis (144). Thus, the clinical relevance of Lcns is rapidly increasing even though the exact mechanisms behind their functions remain to be elucidated.

\section{ANTIMICROBIAL EFFECTOR FUNCTION OF MSCs}

\section{In Vitro Studies}

Most of the data about the antimicrobial properties of MSCs have been obtained from in vitro studies with bacteria, although little data exist about the effect of MSCs on viral, fungal, and parasite pathogens. For both unstimulated and stimulated MSCs, a direct antimicrobial effect has been described (Table 3).

The antimicrobial efficacy of MSCs mediated by AMPs has been described for different sources of stromal cells, although different MoA and antibacterial range have been reported for them. Probably, these variations in the antimicrobial spectrum of MSCs might be a specific response of MSCs to produce the most effective AMPs against a specific type of pathogen challenge. A summary of the types of AMPs detected and not detected in the different sources of MSCs are shown in Table 4. Likewise, the data available to date suggest notable species-specific difference between murine and human MSCs with regard to the MoA of the antimicrobial effector function of MSCs (16).

BMSCs are the most studied source regarding the intrinsic antimicrobial ability of MSCs. In humans, the antimicrobial effect of BMSCs is mediated by LL-37 $(19,23)$ and hepcidin $(20)$.

These AMPs have been detected in both unstimulated and stimulated-BMSC cultures. Respect to LL-37, BMSCs as well as their conditioned medium has demonstrated the property to inhibit the bacterial growth of E. coli, Pseudomonas aeruginosa, 
TABLE 3 | Summary of direct antimicrobial effects of MSCs on bacterial, fungal, parasite, and viral pathogens.

\begin{tabular}{|c|c|c|c|}
\hline MSCs stimuli & Activity & Mechanism of action & Reference \\
\hline Bacteria-stimulated BMSCs & $\begin{array}{l}\text { Growth inhibition of Gram-negative (Escherichia coli, } \\
\text { Pseudomonas aeruginosa) and Gram-positive (S. aureus) }\end{array}$ & $\uparrow\llcorner L-37$ & $(19)$ \\
\hline $\begin{array}{l}\text { Unstimulated and bacteria-stimulated MenSCs } \\
\text { and BMSCs }\end{array}$ & Growth inhibition of a mix of bacteria & $\uparrow$ Hepcidin & (20) \\
\hline $\begin{array}{l}\text { Unstimulated and stimulated BMSCs and } \\
\text { AT-MSCs with inflammatory stimuli }\end{array}$ & $\begin{array}{l}\text { Growth inhibition of Gram-negative ( } P \text {. aeruginosa) and Gram- } \\
\text { positive (S. aureus; S. pneumoniae) }\end{array}$ & $\uparrow \mathrm{LL}-37$ & (23) \\
\hline Bacteria-stimulated UC-MSCs & Growth inhibition of Gram-negative (E. coli) & $\uparrow \mathrm{hBD}-2$ & $(24)$ \\
\hline Stimulated muBMSCs with inflammatory stimuli & Inhibition of bacteria growth & $\uparrow$ Lipocalin-2, $\uparrow$ Phagocytic activity & (26) \\
\hline IFN $\gamma$-stimulated BMSCs & $\begin{array}{l}\text { Growth inhibition of Gram positive (S. aureus; S. epidermidis; } \\
\text { E. faecium; Group B streptococci) and parasite (Toxoplasma } \\
\text { gondii), and reduction in virus replication (CMV and HSV-1) }\end{array}$ & $\uparrow \mathrm{IDO}$ & $(16)$ \\
\hline muBMSCs producing IL-17 & Growth inhibition of Candida albicans & $\uparrow \mathrm{IL}-17$ & (32) \\
\hline
\end{tabular}

MSCs, human mesenchymal stem cells; BMSCs, bone marrow MSCs; muBMSCs, murine BMSCs; MenSCs, menstrual MSCs; AT-MSCs, adipose tissue MSCs; UC-MSCs, umbilical cord MSCs; IFN , interferon gamma; IL, interleukin; hBD-2, human $\beta$-defensin-2; IDO, indoleamine 2,3-dioxygenase; CMV, cytomegalovirus; HSV-1, herpes simplex virus type-1.

TABLE 4 | Summary of AMPs types described in MSCs according to their source of origin.

\begin{tabular}{|c|c|c|c|c|c|c|c|c|}
\hline \multirow[t]{3}{*}{ Type of MSCs } & \multicolumn{8}{|c|}{ Types of AMPs } \\
\hline & \multirow[t]{2}{*}{ LL-37 } & \multirow[t]{2}{*}{ Hepcidin } & \multicolumn{3}{|c|}{$\beta$-Defensins } & \multirow[t]{2}{*}{ SP-D } & \multirow[t]{2}{*}{ Lipocalin-2 } & \multirow[t]{2}{*}{ Reference } \\
\hline & & & hBD-1 & hBD-2 & hBD-3 & & & \\
\hline BMSCs & $\sqrt{ }$ & $\sqrt{ }$ & $x$ & $\sqrt{ } / x$ & $x$ & $x$ & $x$ & $(19,20,23)$ \\
\hline muBMSCs & - & - & - & - & - & - & $\sqrt{ }$ & (26) \\
\hline AT-MSCs & - & - & - & - & - & - & - & (23) \\
\hline MenSCs & $x$ & $\sqrt{ }$ & $x$ & $x$ & $x$ & - & - & (20) \\
\hline UC-MSCS & $x$ & - & - & $\sqrt{ }$ & - & - & $x$ & (24) \\
\hline
\end{tabular}

MSCs, human mesenchymal stem cells; BMSCs, bone marrow MSCs; muBMSCs, murine BMSCs; MenSCs, menstrual MSCs; AT-MSCs, adipose tissue MSCs; UC-MSCs, umbilical blood cord MSCs; $h B D$, human $\beta$-defensin; SP-D, surfactant protein-D; $\sqrt{ }$, detected; $x$, not detected; -, not determined.

S. aureus, and S. pneumonia $(19,23)$. In the study performed by Krasnodembskaya et al. (19), the authors showed that BMSCs are able to inhibit bacterial growth directly, also by means of conditioned culture medium, but only when BMSCs were previously challenged with bacteria. They also showed that BMSCs produce and secrete inducible quantities of LL-37, responsible for the inhibition of bacterial growth of $E$. coli and $P$. aeruginosa in vitro. In contrast, hBD-2-3, Lcn2, and surfactant protein D (SPD) were negative in BMSCs or expressed very low protein levels, which were insufficient to elicit an antibacterial effect. Likewise, these cells exhibit direct antimicrobial activity against $S$. aureus, through a contact-independent mechanism and mediated in part by the release of LL-37. Recently, Sutton et al. (23). demonstrated that BMSCs constitutively secrete LL-37, which exert a potent antimicrobial effect in vitro against $P$. aeruginosa, $S$. aureus, and S. pneumonia, controlling the rate of bacterial growth and transition into colony forming units. These data suggest that BMSCs supernatants can be useful as an adjunct treatment to conventional ABs. Interestingly, the levels of LL-37 were enhanced after the preconditioning with inflammatory stimulus, as IFN $\gamma$, IL-1 $\beta$, or IL-12. However, in line with previous report $(19,20)$, the levels of hBD-2-3 were not detected in unstimulated nor stimulated BMSCs (23). Furthermore, the levels of LL-37 were detected in BMSCs only when the cell growth was performed under FBS (fetal bovine serum) condition, since the serum-free or platelet lysate conditions reduce the antimicrobial efficacy of
BMSCs and their production of LL-37 (23). Conversely with the aforementioned data, in which expression of the antimicrobial peptide LL-37 was detected constitutively in BMSCs or following stimulation with E. coli or inflammatory stimulus, data from our research group did not show any basal or induced expression of LL-37 under both bacterial mixture and LPS stimulations in BMSCs. However, we detected in bacteria-stimulated BMSCs the expression of hepcidin, which was involved in the antimicrobial effect of MSCs both direct and in conditioned medium (20).

The antimicrobial properties of MSCs is not only limited to AMPs activity. In fact, upon stimulation with inflammatory cytokines, BMSCs through a substantial increase in IDO expression, exhibit a cell autonomous, broad-spectrum antimicrobial effector function directed against clinically relevant bacteria (S. aureus; S. epidermidis; E. faecium; Group B streptococci), protozoal parasites (Toxoplasma gondii), and viruses (CMV and HSV-1) (16). Also, it has been reported that IL-17-positive murine $(\mathrm{mu}) \mathrm{BMSC}$ exert a potent antifungal activity with respect to IL-17-negative or bulk muBMSCs. The growth inhibition of Candida albicans is mediated by IL-17 in a dose-dependent manner, while anti-IL-17 antibodies partially reduce anti-C. albicans effect of muBMSCs (32).

Potent antimicrobial effects of muBMSCs have also been described on E. coli and C. albicans but with a different MoA with respect to their human counterpart. As reviewed by Balan et al. (165), no data indicate secretion of LL-37 by 
muBMSCs, but the preconditioning with E. coli significantly increases the production of the antimicrobial protein Lcn2 (26). Furthermore, in contrast to BMSCs of human origin, muBMSCs fail to express IDO even after stimulation with inflammatory cytokines such as IFN $\gamma$, tumor necrosis alpha, and IL-1 $\beta$, and they consequently do not inhibit bacterial growth (16). However, it has been reported that unstimulated muBMSCs directly exhibit phagocytic activity for E. coli or $S$. aureus in a cell dose-dependent manner (25), although further studies are required to confirm these claims.

More recently, menstrual fluid-derived MSCs (MenSCs) have emerged as an attractive alternative for cell therapy since they are isolated in a non-invasive manner with the possibility of periodical collections from the same donor, ensuring high amounts of cells at low culture passages and from the same genetic background $(2,6)$. Our group has recently shown that MenSCs have an important antimicrobial effect mediated by hepcidin, both directly and through the peptide present in their conditioned medium. Polybacterial stimulation significantly increased the expression of hepcidin in MenSCs, whereas other antimicrobial peptides such as LL-37 and hBD-1-2-3 remained below the limit of detection (20). Interestingly, the downregulation of hepcidin through hypoxic condition resulted in the loss of the antimicrobial property of MenSCs, indicating a hepcidindependent mechanism (20). Therefore, culture condition need to be carefully considered when expanding MenSCs as any modification in the oxygen levels can affect their biological activities and consequently, their antimicrobial potential. In that perspective, the effect of hypoxia on MenSCs functions could be considered as a negative regulator of their antimicrobial activity (20) but is contrasted with a positive effect on their angiogenic property (2). Nevertheless, the extend of the effect of this type of conditioning is largely dependent on the source of MSCs, as an example, it has been observed that the immunosuppressive capacity of AT-MSCs remains unchanged under hypoxic conditions (166).

Sung et al. (24) described that the growth of E. coli in vitro was significantly inhibited by UC-MSCs or their conditioned medium after bacterial exposure. In microarray analysis performed to detect gene expression changes in MSCs responsible for their antibacterial action, a significant upregulation of tolllike receptor (TLR)-2 and TLR-4, and hBD-2 were identified in UC-MSCs after E. coli exposure, suggesting that the antimicrobial effects of MSCs might be mediated by the secretion of hBD-2 via TLR signaling pathway. However, the increased hBD-2 level and the in vitro antibacterial effects of MSCs were abolished by specific antagonist or by silencing of the TLR-4, but not TLR-2. The effect was restored by $\mathrm{hBD}-2$ supplementation, indicating that hBD-2 secreted by MSCs only via TLR- 4 mediates the antibacterial effects. In this study, the gene expression profiles of other antimicrobial proteins, such as LL-37 $(19,23)$ or Lcn2 $(26)$, were not significantly upregulated.

AT-MSCs or their conditioned medium have also shown an antimicrobial effect. Sutton et al. (23) report that the conditioned medium of AT-MSCs decreased the $P$. aeruginosa growth rate to levels comparable with the $\mathrm{AB}$ geneticin, a broad-spectrum aminoglycoside AB. Importantly, the combination of AT-MSCs with geneticin showed a potent antimicrobial effect against
$P$. aeruginosa, revealing that this type of stromal cells have an AB-enhancing effect.

\section{In Vivo Studies}

The in vitro data demonstrating the antimicrobial effect of MSCs have also been supported by in vivo studies. MSCs from different sources or origins have the capability to reduce the burden of pathogens in different preclinical models, independently of the route of administration, doses, or time of injections, having been shown in blood, spleen, peritoneum, lung, and bronchoalveolar lavage (BAL) fluid (17-23, 25, 26, 30). In Table 5, we summarize the current in vivo data regarding antimicrobial effector function of MSCs mediated by AMPs.

In an immunocompetent model of pneumonia by $E$. coli, the treatment with $1 \times 10^{6} \mathrm{BMSC}$ after $4 \mathrm{~h}$ of $E$. coli instillation induced a sharp reduction in total bacterial counts in lung homogenates (LH) and BAL fluid compared with vehicle (19). Total BAL cell counts and absolute neutrophil counts were also lower in the BMSCs-treated group, suggesting that bacterial clearance in the BAL of BMSC-treated mice did not primarily depend on the recruitment of immune cells. In fact, the administration of BMSCs together with neutralizing anti-LL-37 antibody resulted in a 10-fold increase in bacterial number both in $\mathrm{LH}$ and $\mathrm{BAL}$, revealing that LL-37 effect is needed for the antimicrobial activity of BMSCs in vivo (19). These results are in line with Sung's work (24), where in the same model, the treatment with $1 \times 10^{5}$ UC-MSCs administered intratracheally after $3 \mathrm{~h}$ of $E$. coli instillation provoke a downregulation of the inflammatory response and enhanced bacterial clearance, increased hBD-2 secretion in BAL fluid and the resultant protection against $E$. coli-induced pneumonia. Since hBD-2 secreted by MSCs are via the TLR- 4 pathway, the antibacterial effects of UC-MSCs were abolished with TLR-4 siRNA transfection of UC-MSCs. Likewise, the detection of hBD-2 in BAL fluid, suggests that hBD-2 secreted by transplanted UC-MSCs plays a pivotal role in mediating the in vivo antibacterial effects of UC-MSCs (24). Similarly, another study with similar preclinical model setting described that the concentration of the antimicrobial molecule Lcn 2 in BAL fluid is increased after the transplantation of muBMSCs; and the blocking of Lcn 2 by a monoclonal antibody results in the elimination of the antibacterial effect of MSCs treatment in vivo (26).

In immunocompetent mice with a polymicrobial sepsis induced by cecal ligation and puncture (CLP), the administration of MSCs, either of human or murine origin, induced a reduction of the burden of pathogens and also a significant improvement in the survival rate $(17,20,22,25,30)$. Our group has recently shown that the administration of $7.5 \times 10^{5}$ MenSCs $3 \mathrm{~h}$ after CLP-induced sepsis is able to reduce the animal mortality regulating different aspects of the septic process, such as the organ dysfunction, modulation of the inflammatory response without severe immunosuppression, and promotion of bacterial clearance in blood, in a similar degree to the present standard of treatment with $A B$ therapy (20). Notably, the synergism between MenSCs $+\mathrm{AB}$ resulted in the highest improvement of survival (20). Although the in vivo role of hepcidin was not evaluated, the in vitro data suggest a potential antibacterial effect of hepcidin in the resolution of the bacteremia. In line with these data, 
TABLE 5 | Summary of studies reporting direct antibacterial effect of MSCs by AMPs.

\begin{tabular}{|c|c|c|c|c|c|}
\hline Model & $\begin{array}{l}\text { MSCs type/ } \\
\text { route }\end{array}$ & $\begin{array}{l}\text { Pre- } \\
\text { conditioning }\end{array}$ & In vitro findings & In vivo findings & Reference \\
\hline $\begin{array}{l}\text { Mouse model of } \\
\text { Escherichia coli pneumonia } \\
\text { (C57BL/6 mice) }\end{array}$ & BMSCs/it & E. coli & $\begin{array}{l}\uparrow \mathrm{LL}-37 \\
\uparrow \text { Inhibition of bacterial } \\
\text { growth (E. coli, Pseudomonas } \\
\text { aeruginosa, S. aureus) }\end{array}$ & $\downarrow$ Bacterial growth in lungs and in BAL fluid & (19) \\
\hline $\begin{array}{l}\text { Mouse model of CLP- } \\
\text { induced sepsis (C57BL/6j } \\
\text { mice) }\end{array}$ & MenSCs/ip & $\begin{array}{l}\text { Unstimulated } \\
\text { and stimulated } \\
\text { with bacterial } \\
\text { mix }\end{array}$ & $\begin{array}{l}\uparrow \text { Hepcidin } \\
\uparrow \text { Inhibition of bacterial growth }\end{array}$ & $\begin{array}{l}\uparrow \text { Survival } \\
\downarrow \text { Lung injury } \\
\uparrow \text { Bacterial clearance in the peritoneal fluids and blood } \\
\text { Modulation of inflammatory response }\end{array}$ & (20) \\
\hline $\begin{array}{l}\text { Mouse model of cystic } \\
\text { fibrosis (CFTR }{ }^{\text {tmIKth }} \text { mice) }\end{array}$ & $\begin{array}{l}\text { BMSCs } \\
\text { AT-MSCs/ } \\
\text { retro-orbital } \\
\text { sinus }\end{array}$ & $\begin{array}{l}\text { Unstimulated } \\
\text { and stimulated } \\
\text { with IFN } \gamma, \mathrm{IL}-1 \beta \\
\text { or IL-12 }\end{array}$ & $\begin{array}{l}\uparrow \mathrm{LL}-37 \\
\uparrow \text { Inhibition of bacterial growth } \\
\text { (P. aeruginosa; S. aureus; S. } \\
\text { pneumoniae) }\end{array}$ & $\downarrow$ Bacterial growth in BAL fluid & (23) \\
\hline $\begin{array}{l}\text { Mouse model of } E \text {. coli } \\
\text { pneumonia (ICR mice) }\end{array}$ & UC-MSCs/it & E. coli & $\begin{array}{l}\uparrow \mathrm{hBD}-2 \\
\uparrow \text { Inhibition of bacterial growth } \\
\text { (E. coli) }\end{array}$ & $\begin{array}{l}\downarrow \text { Alveolar congestion, hemorrhage, neutrophil } \\
\text { infiltration, and wall thickening } \\
\downarrow \text { Bacterial growth, protein concentrations and cytokine } \\
\text { levels (IL-1 } \alpha, I L-1 \beta, I L-6 \text {, and TNF } \alpha \text { ) in BAL fluid } \\
\uparrow h B D-2 \text { in BAL fluid }\end{array}$ & (24) \\
\hline $\begin{array}{l}\text { Mouse model of Gram- } \\
\text { negative pneumonia } \\
\text { (C57BL/6 mice) }\end{array}$ & muBMSCs/it & LPS and $T N F \alpha$ & $\begin{array}{l}\uparrow \text { Lipocalin-2 } \\
\uparrow \text { Phagocytic activity }\end{array}$ & $\begin{array}{l}\uparrow \text { Survival } \\
\downarrow \text { Lung injury } \\
\uparrow \text { Bacterial clearance from the alveolar space } \\
\downarrow \text { MIP-2, TNF } \alpha \text {, and MPO in BAL fluid } \\
\uparrow \text { Lipocalin-2 in BAL fluid }\end{array}$ & $(26)$ \\
\hline
\end{tabular}

MSCs, mesenchymal stem cells; BMSCs, bone marrow MSCs; muBMSCs, murine BMSCs; MenSCs, menstrual MSCs; AT-MSCs, adipose tissue MSCs; UC-MSCs, umbilical cord MSCs; it, intratracheal; ip, intraperitoneal; CLP, cecal ligation and puncture; BAL, bronchoalveolar lavage; CM, conditioned media; IFN $\gamma$, interferon gamma; IL, interleukin; $h B D-2$, human $\beta$-defensin-2; TNF $\alpha$, tumor necrosis factor alpha; LPS, lipopolysaccharide; MIP-2, macrophage inflammatory protein 2; MPO, myeloperoxidase.

Gonzalez-Rey et al. (17) described that AT-MSCs-treated septic mice have lower peritoneal bacterial counts than untreated mice, suggesting that AT-MSCs could promote bactericidal activities by themselves or on other cell types. Concordantly, Mei et al. (25) reported that $2.5 \times 10^{5}$ muBMSCs administered $6 \mathrm{~h}$ after CLP-induced sepsis results in a higher bacterial clearance in part due to enhanced phagocytotic activity of the host immune cells.

Cystic fibrosis is a genetic disease in which the battle between pulmonary infection and inflammation becomes the major cause of morbidity and mortality. In a mouse model of cystic fibrosis infected with $P$. aeruginosa and $S$. aureus, the administration of $1 \times 10^{6} \mathrm{BMSC}$ or its conditioned medium results in a reduction of the CFU of these two pathogens in BAL fluid. Although the role of the peptide LL-37 was not evaluated in vivo, the in vitro data showing the constitutive or stimulated expression of LL-37 suggest a potential role for this peptide in the reduction of bacterial growth in vivo (23).

\section{ARE ANTIMICROBIAL EXTRACELLULAR VESICLES, THE NEXT BIG THING FOR INFECTIOUS DISEASES?}

Extracellular vesicles released by cells act as key agents in intercellular communications through transfer of information via their cargo, which includes proteins, DNAs, and RNAs (167). The active biological role of cell-derived vesicles in pathological conditions such as ischemic heart disease, kidney injury, and wound healing have been shown to share many similar therapeutical features of their parent cells (15). While EVs [mainly microvesicles (MVs) and exosomes] are gaining momentum in the regenerative medicine field as a putative surrogate to cell-based therapeutics (168) their application in infectious diseases still requires further exploration.

Recently, AMPs were identified in different EVs isolated from body fluids and selective enrichment was related to specific diseases. Hiemstra et al. (169) reported that exosomes isolated from normal human urine contain innate immune proteins that include antimicrobial agents. The analyzed list included lysozyme C, dermcidin, mucin-1, calprotectin, and myeloperoxidase, all known for their bactericidal effect. The antimicrobial activity of urinary exosomes was determined through their in vitro incubation with E. coli, reporting that these exosomes were able to induce bacterial lysis and inhibit their growth in vitro, observations that reinforce the claim that exosomes are innate immune effectors that contribute to host defense. Similarly, exosomes isolated from nasal lavage fluids were shown to contain proteins with immunerelated functions relevant in the first line of defense against pathogens and allergens. Thus, the analysis of the alterations in the exosomes proteome as a result of a chronic airway inflammation revealed that serum-associated proteins and mucins were more abundant in exosomes from subjects with airway diseases compared to healthy subjects while proteins with antimicrobial functions and barrier-related proteins had decreased expression (170). Also, biliary and intestinal epithelium luminal release exosomes that are increased following infection by a protozoan 
parasite, carrying AMPs of epithelial cell origin, including LL-37 and hBD-2. Activation of TLR-4 signaling enhances exosomemediated shuttle of epithelial AMPs from the gastrointestinal epithelium, revealing a new arm of mucosal immunity relevant to antimicrobial defense (171).

As discussed in this review, MSCs exert strong antimicrobial effects through paracrine release of several antimicrobial factors. However, future experimental designs are still required to demonstrate whether some of these effects are mediated by EVs.

\section{Potential Antibacterial Activity of EVs Released from MSCs}

Recent studies have ignited significant interest on EVs released by MSCs accounting, at least in part, on their paracrine effect resulting in a horizontal transfer of the nucleic acids and proteins between the injured cells and MSCs. This cell-to-cell interaction is doubt to be bi-directional, resulting in reprogramming of their secretome to respond to specific need of the tissue by transferring to the injured cells, factors restraining injury, and leading to tissue regeneration. MSCs-derived EVs have been implicated in the tissue restoring effects of MSCs including, anti-apoptotic (172), wound healing (173), and anti-tumoral activities (168).

In the last few years, the beneficial role of MSCs-derived EVs has been described in several preclinical models of inflammatory/ infectious diseases. Zhu et al. (174) reported that MVs released by BMSCs were therapeutically effective following E. coli endotoxininduced acute lung injury (ALI) in mice, in part through the transfer of keratinocyte growth factor (KGF) mRNA from the MVs to the injured alveolar epithelium and lung endothelium. In line, Monsel et al. showed that the administration of MVs secreted by BMSCs improved survival, and decreased the influx of inflammatory cells and bacteria in a bacterial pneumonia mouse model. The antimicrobial effect of BMSCs-derived MVs was in part through enhancement of monocyte phagocytosis of bacteria, which could be further increased by pre-stimulation of BMSCs with a TLR-3 agonist before the release of MVs (175). However, it remains to be explored whether MVs released from MSCs conserve the cell antimicrobial effect through their AMPs content. Future experimental designs are required to explicitly address their antimicrobial relevance in the previously evaluated infectious disease models. Furthermore, the exposure of MSCs to conditions that are known to upregulate the expression of AMPs such as cytokines (IFN $\gamma$, TNF $\alpha$, IL-22, etc.), growth factors, and UV exposure should be considered (Figure 1). Additionally, the effect of the conditioning on increasing the MVs cargo content with AMPs will also need to be evaluated. Nevertheless, in other applications, it has been demonstrated that MVs can transport drugs to target sites and maintain a higher drug concentration than conventional dosage forms. Tang et al. engineered drug-packaging MVs by incubating cells with chemotherapeutic agents. These hybrid MVs were used to effectively kill tumor cells in murine tumor models without typical side effects (176). More recently, another group assessed the feasibility of an exosome-based drug by loading a chemotherapeutic agent through sonication to treat multidrug-resistant cancer. Interestingly they observed a 50-fold increase in the cytotoxicity in drug-resistant cancer cells (177).
This is a relevant outcome as it limits the side effect related to the conventional administration of chemotherapies and advance a novel and sustained drug release method.

Similar drug loading strategy could be evaluated based on AMPs packaging in EVs. The rationale for EVs loaded with AMPs is the possibility to enhance their therapeutic potential through increasing their concentrations at the site of infection and/or by reducing the toxicity of ABs.

\section{TRENDS, FUTURE PERSPECTIVES, AND CHALLENGES}

Aside from the direct administration of synthetic or natural AMPs through drug or MSCs infusion, there are several ongoing clinical studies aimed at modulating the expression of AMPs by the endogenous cells in the body, through dietary nutrients and vitamins, to boost the innate immune response (178). Indeed, Vitamin D3 has been shown to directly regulate expression of the human antimicrobial peptides LL-37 and hBD-2 $(179,180)$. However, a recent pilot study in mechanically ventilated ICU patients showed that high dose of vitamin D3 was associated with decreased hospital length of stay, but no statically significant change in plasma LL-37 concentrations or other clinical outcomes (181). While the stimulatory effect of Vitamin D has been described for the osteogenic potential of MSCs (182), future experiments are required to address their effect on the expression of AMPs both in vitro and in vivo. This could represent an alternative approach by stimulating the endogenous MSCs to secrete higher amount of AMPs.

The urgent need for new strategies has become evident due to increasing drug resistance. Discovering new classes of antimicrobials or AMPs is a very promising approach but it might not be the only strategy required for defeating this threat. In fact, enhancing AMPs delivery, bioavailability, liberation, absorption, half-life while reducing their clearance and side effect can also denote an additional booster for overcoming infections.

Mesenchymal stem cells present desirable features to improve the pharmacokinetics of natural AMPs, their stem cell-related "arsenal" includes

(a) Sensors, able to detect and react following an infection signal, triggering an immediate mobilization and a migration shift toward the site of infection.

(b) Bioactive pumps, able to control on-demand the continuous release of AMPs in the site of infection.

(c) Watchtowers, able to release specific combinations of AMPs depending on the stimulus.

Standpoint efforts focusing on enhancing these MSC features through genetic modifications or preconditioning, in addition to deciphering the multi-target drug status of AMPs (indirect and direct targets), should synergistically lead to key advances against infections caused by drug-resistant strains. Nonetheless, despite these advantageous features, there are still some challenges hindering their applications, such as high production costs (when compared to generic ABs), in addition to storage 


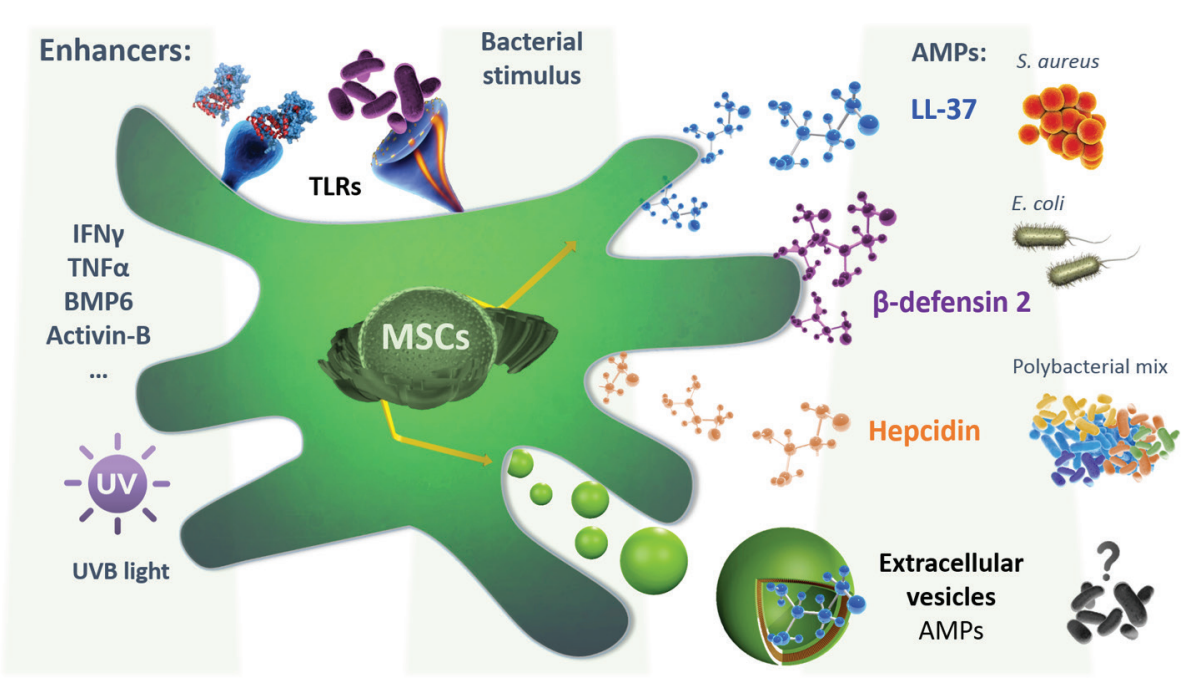

FIGURE 1 | A schematic representation depicting the mesenchymal stem cells (MSCs) secretion of different AMPs, following different hypothetical preconditioning to enhance their expression, secretion, or encapsulation in extracellular vesicles (EVs), based on the known regulation of the expression of each AMPs. Also, the bacterial or inflammatory stimulation is shown. LL-37 secretion was shown to possess a bactericide effect on both S. aureus and Escherichia coli, while the $\beta$-defensin-2 effect was demonstrated in $E$. coli alone. MSCs isolated from menstrual fluids were able to secrete hepcidin that was shown to inhibit the growth of a polybacterial mix isolated from mice microflora. Extracellular vesicles can also be secreted by MSCs and possibly contain active agents with potential antimicrobial effect. This will require further investigation in the future. Abbreviations: IFN $\gamma$, interferon gamma; TNF $\alpha$, tumor necrosis factor alpha; BMP6, bone morphogenetic protein 6; AMPs, antimicrobial peptides.

problems including "off-the-shelf" and ready-to-use dosage shortage.

New perspective tools based on unmodified or drug-loaded EVs are looming in the horizon. These thriving alternatives need further development and investigation to achieve maximum killing efficiency, less side effects, and null drug-resistant infections. Indeed, the prospect of using concentrations below the minimum inhibitory concentration might contribute to limit the emergence of $\mathrm{AB}$ resistance due to drug-resistant strains. However, one should keep in mind that the mechanism and effect of EVs on extracellular bacterial clearance might be different in comparison to intracellular bacteria, and this will require additional consideration in the experimental design. The actual trend in the field positions MSCs-derived EVs (with or without drug loading), as important candidates to be exploited as novel "ready-to-inject" biologics, in infectious diseases as an alternative to stem cellbased therapy.

\section{CONCLUSION}

Mesenchymal stem cells exert strong antimicrobial effects through indirect and direct mechanisms, partially through the secretion of AMPs. The bacterial clearance observed in preclinical models including sepsis, ARDS, and cystic fibrosis infection, can be further enhanced following specific preconditioning protocols. We propose possible strategies to increase the expression and secretion of these AMPs to enhance their antimicrobial effect. These conditions include the exposure of MSCs to cytokines, growth factors, and UVB light. Furthermore, studies evaluating the presence of AMPs in the cargo of EVs will represent an opportunity to develop new drug delivery tools. The potential antimicrobial activity of MSCs-derived EVs can also be heightened through cell conditioning and/or drug loading. Finally, the enhanced antimicrobial potential of MSCs through AMPs secretion or encapsulation present an important potential to be exploited as an improved therapeutic approach for infectious diseases.

\section{AUTHOR CONTRIBUTIONS}

All authors listed have made substantial, direct, and intellectual contribution to the work and approved it for publication.

\section{ACKNOWLEDGMENTS}

The authors specially thank Dr. Fernando Figueroa and Dr. Francisco Espinoza (Medicine Faculty, Universidad de los Andes, Santiago, Chile) for their helpful scientific and clinical discussions.

\section{FUNDING}

This work was funded by Cells for Cells (Santiago, Chile), Consorcio Regenero (Santiago, Chile) and by the Chilean National Commission for Scientific and Technological Investigation (CONICYT), FONDEF IDeA Instrument, grant number IT16I10084. 


\section{REFERENCES}

1. González PL, Carvajal C, Cuenca J, Alcayaga-Miranda F, Figueroa FE, Bartolucci J, et al. Chorion mesenchymal stem cells show superior differentiation, immunosuppressive, and angiogenic potentials in comparison with haploidentical maternal placental cells. Stem Cells Transl Med (2015) 4:1109-21. doi:10.5966/sctm.2015-0022

2. Alcayaga-Miranda F, Cuenca J, Luz-Crawford P, Aguila-Díaz C, Fernandez A, Figueroa FE, et al. Characterization of menstrual stem cells: angiogenic effect, migration and hematopoietic stem cell support in comparison with bone marrow mesenchymal stem cells. Stem Cell Res Ther (2015) 6:32. doi:10.1186/ s13287-015-0013-5

3. Prockop DJ, Kota DJ, Bazhanov N, Reger RL. Evolving paradigms for repair of tissues by adult stem/ progenitor cells (MSCs). J Cell Mol Med (2010) 14:2190-9. doi:10.1111/j.1582-4934.2010.01151.x

4. Luz-Crawford P, Torres MJ, Noël D, Fernandez A, Toupet K, AlcayagaMiranda F, et al. The immunosuppressive signature of menstrual blood mesenchymal stem cells entails opposite effects on experimental arthritis and graft versus host diseases. Stem Cells (2016) 3:456-69. doi:10.1002/ stem. 2244

5. Ren H, Sang Y, Zhang F, Liu Z, Qi N, Chen Y. Comparative analysis of human mesenchymal stem cells from umbilical cord, dental pulp, and menstrual blood as sources for cell therapy. Stem Cells Int (2016) 2016:3516574. doi: $10.1155 / 2016 / 3516574$

6. Khoury M, Alcayaga-Miranda F, Illanes SE, Figueroa FE. The promising potential of menstrual stem cells for antenatal diagnosis and cell therapy. Front Immunol (2014) 5:1-8. doi:10.3389/fimmu.2014.00205

7. Billing AM, Ben Hamidane H, Dib SS, Cotton RJ, Bhagwat AM, Kumar P, et al. Comprehensive transcriptomic and proteomic characterization of human mesenchymal stem cells reveals source specific cellular markers. Sci Rep (2016) 6(21507):1-15. doi:10.1038/srep21507

8. Dominici M, Le Blanc K, Mueller I, Slaper-Cortenbach I, Marini F, Krause D, et al. Minimal criteria for defining multipotent mesenchymal stromal cells. The International Society for Cellular Therapy position statement. Cytotherapy (2006) 8:315-7. doi:10.1080/14653240600855905

9. Le Blanc K, Frassoni F, Ball L, Locatelli F, Roelofs H, Lewis I, et al. Mesenchymal stem cells for treatment of steroid-resistant, severe, acute graft-versus-host disease: a phase II study. Lancet (2008) 371:1579-86. doi:10.1016/S0140-6736(08)60690-X

10. Chamberlain G, Fox J, Ashton B, Middleton J. Concise review: mesenchymal stem cells: their phenotype, differentiation capacity, immunological features, and potential for homing. Stem Cells (2007) 25:2739-49. doi:10.1634/ stemcells.2007-0197

11. Liang X, Ding Y, Zhang Y, Tse H, Lian Q. Paracrine mechanisms of mesenchymal stem cell-based therapy: current status and perspectives. Cell Transplant (2014) 23:1045-59. doi:10.3727/096368913X667709

12. Pacini S, Petrini I. Are MSCs angiogenic cells? New insights on human nestin-positive bone marrow-derived multipotent cells. Front Cell Dev Biols (2014) 2:1-11. doi:10.3389/fcell.2014.00020

13. Otsu K, Das S, Houser SD, Quadri SK, Bhattacharya S, Bhattacharya J. Concentration-dependent inhibition of angiogenesis by mesenchymal stem cells. Blood (2009) 113:4197-205. doi:10.1182/blood-2008-09-176198

14. Lai RC, Arslan F, Lee MM, Sze NSK, Choo A, Chen TS, et al. Exosome secreted by MSC reduces myocardial ischemia/reperfusion injury. Stem Cell Res (2010) 4:214-22. doi:10.1016/j.scr.2009.12.003

15. Alcayaga-Miranda F, Varas-Godoy M, Khoury M. Harnessing the angiogenic potential of stem cell-derived exosomes for vascular regeneration. Stem Cells Int (2016) 2016:3409169. doi:10.1155/2016/3409169

16. Meisel R, Brockers S, Heseler K, Degistirici O, Bülle H, Woite C, et al. Human but not murine multipotent mesenchymal stromal cells exhibit broad-spectrum antimicrobial effector function mediated by indoleamine 2, 3-dioxygenase. Leukemia (2011) 25:648-54. doi:10.1038/leu.2010.310

17. Gonzalez-Rey E, Anderson P, González MA, Rico L, Büscher D, Delgado M. Human adult stem cells derived from adipose tissue protect against experimental colitis and sepsis. Gut (2009) 58:929-39. doi:10.1136/ gut.2008.168534

18. Krasnodembskaya A, Samarani G, Song Y, Zhuo H, Su X, Lee J-W, et al. Human mesenchymal stem cells reduce mortality and bacteremia in gram-negative sepsis in mice in part by enhancing the phagocytic activity of blood monocytes. Am J Physiol Lung Cell Mol Physiol (2012) 302:L1003-13. doi:10.1152/ajplung.00180.2011

19. Krasnodembskaya A, Song Y, Fang X, Gupta N, Serikov V, Lee J-W, et al. Antibacterial effect of human mesenchymal stem cells is mediated in part from secretion of the antimicrobial peptide LL-37. Stem Cells (2010) 28:2229-38. doi:10.1002/stem.544

20. Alcayaga-Miranda F, Cuenca J, Martin A, Contreras L, Figueroa FE, Khoury M. Combination therapy of menstrual derived mesenchymal stem cells and antibiotics ameliorates survival in sepsis. Stem Cell Res Ther (2015) 6:199. doi:10.1186/s13287-015-0192-0

21. Lee JW, Krasnodembskaya A, Mckenna DH, Song Y, Abbott J, Matthay MA. Therapeutic effects of human mesenchymal stem cells in ex vivo human lungs injured with live bacteria. Am J Respir Crit Care Med (2013) 1:751-60. doi:10.1164/rccm.201206-0990OC

22. Németh K, Leelahavanichkul A, Yuen PST, Mayer B, Parmelee A, Doi K, et al. Bone marrow stromal cells attenuate sepsis via prostaglandin $\mathrm{E}(2)$-dependent reprogramming of host macrophages to increase their interleukin-10 production. Nat Med (2009) 15:42-9. doi:10.1038/nm0409-462b

23. Sutton MT, Fletcher D, Ghosh SK, Weinberg A, Van Heeckeren R, Kaur $\mathrm{S}$, et al. Antimicrobial properties of mesenchymal stem cells: therapeutic potential for cystic fibrosis infection and treatment. Stem Cells Int (2016) 2016:12. doi:10.1155/2016/5303048

24. Sung DK, Chang YS, Sung SI, Yoo HS, Ahn SY, Park WS. Antibacterial effect of mesenchymal stem cells against Escherichia coli is mediated by secretion of beta-defensin-2 via toll-like receptor 4 signalling. Cell Microbiol (2016) 18:424-36. doi:10.1111/cmi.12522

25. Mei SHJ, Haitsma JJ, Dos Santos CC, Deng Y, Lai PFH, Slutsky AS, et al. Mesenchymal stem cells reduce inflammation while enhancing bacterial clearance and improving survival in sepsis. Am J Respir Crit Care Med (2010) 182:1047-57. doi:10.1164/rccm.201001-0010OC

26. Gupta N, Krasnodembskaya A, Kapetanaki M, Mouded M, Tan X, Serikov $\mathrm{V}$, et al. Mesenchymal stem cells enhance survival and bacterial clearance in murine Escherichia coli pneumonia. Thorax (2012) 67(6):533-40. doi:10.1136/thoraxjnl-2011-201176

27. Maqbool M, Vidyadaran S, George E, Ramasamy R. Human mesenchymal stem cells protect neutrophils from serum-deprived cell death. Cell Biol Int (2011) 35:1247-51. doi:10.1042/CBI20110070

28. Cassatella MA, Mosna F, Micheletti A, Lisi V, Tamassia N, Cont C, et al. Toll-like receptor-3-activated human mesenchymal stromal cells significantly prolong the survival and function of neutrophils. Stem Cells (2011) 29:1001-11. doi:10.1002/stem.651

29. Raffaghello L, Bianchi G, Bertolotto M, Montecucco F, Busca A, Dallegri F, et al. Human mesenchymal stem cells inhibit neutrophil apoptosis: a model for neutrophil preservation in the bone marrow niche. Stem Cells (2008) 26:151-62. doi:10.1634/stemcells.2007-0416

30. Hall SR, Tsoyi K, Ith B, Padera RF, Lederer JA, Wang Z, et al. Mesenchymal stromal cells improve survival during sepsis in the absence of heme oxygenase-1: the importance of neutrophils. Stem Cells (2013) 31:397-407. doi: $10.1002 /$ stem. 1270

31. Kim JHP. Mesenchymal stem cell-educated macrophages: a novel type of alternatively activated macrophages. Exp Hematol (2010) 37:1445-53. doi:10.1016/j.exphem.2009.09.004.Mesenchymal

32. Yang R, Liu Y, Kelk P, Qu C, Akiyama K, Chen C, et al. A subset of IL-17 + mesenchymal stem cells possesses anti-Candida albicans effect. Cell Res (2012) 23:107-21. doi:10.1038/cr.2012.179

33. Brogden KA. Antimicrobial peptides: pore formers or metabolic inhibitors in bacteria? Nat Rev Microbiol (2005) 3:238-50. doi:10.1038/ nrmicro 1098

34. Zhang L, Gallo RL. Antimicrobial peptides. Curr Biol (2016) 26:R14-9. doi:10.1016/j.cub.2015.11.017

35. Wang G. Human antimicrobial peptides and proteins. Pharmaceuticals (Basel) (2014) 7:545-94. doi:10.3390/ph7050545

36. Dutta P, Das S. Mammalian antimicrobial peptides: promising therapeutic targets against infection and chronic inflammation. Curr Top Med Chem (2016) 16:99-129. doi:10.2174/1568026615666150703121819

37. Bahar AA, Ren D. Antimicrobial peptides. Pharmaceuticals (Basel) (2013) 6:1543-75. doi:10.3390/ph6121543 
38. Seo M-D, Won H-S, Kim J-H, Mishig-Ochir T, Lee B-J. Antimicrobial peptides for therapeutic applications: a review. Molecules (2012) 17:12276-86. doi:10.3390/molecules171012276

39. Mangoni ML. Host-defense peptides: from biology to therapeutic strategies. Cell Mol Life Sci (2011) 68:2157-9. doi:10.1007/s00018-011-0709-3

40. Fabisiak A, Murawska N, Fichna J. LL-37: cathelicidin-related antimicrobial peptide with pleiotropic activity. Pharmacol Rep (2015) 68:802-8. doi:10.1016/j.pharep.2016.03.015

41. Burian M, Schittek B. The secrets of dermcidin action. Int J Med Microbiol (2015) 305:283-6. doi:10.1016/j.ijmm.2014.12.012

42. Krensky AM, Clayberger C. Biology and clinical relevance of granulysin. Tissue Antigens (2009) 73:193-8. doi:10.1111/j.1399-0039.2008.01218.x

43. Helmerhorst EJ, Troxler RF, Oppenheim FG. The human salivary peptide histatin 5 exerts its antifungal activity through the formation of reactive oxygen species. Proc Natl Acad Sci U S A (2001) 98(25):14637-42. doi:10.1073/ pnas. 141366998

44. Gifford JL, Hunter HN, Vogel HJ. Lactoferricin: a lactoferrin-derived peptide with antimicrobial, antiviral, antitumor and immunological properties. Cell Mol Life Sci (2005) 6205:2588-98. doi:10.1007/s00018-005-5373-z

45. Wu T, Samaranayake LP, Leung WK, Sullivan PA. Inhibition of growth and secreted aspartyl proteinase production in Candida albicans by lysozyme. J Med Microbiol (1999) 48:721-30. doi:10.1099/00222615-48-8-721

46. Gläser R, Köten B, Wittersheim M, Harder J. Psoriasin: key molecule of the cutaneous barrier? JDtsch Dermatol Ges (2011) 9:897-902. doi:10.1111/j.1610-0387.2011.07683.x

47. Ericksen B, Wu Z, Lu W, Lehrer RI. Antibacterial activity and specificity of the six human \{alpha\}-defensins. Antimicrob Agents Chemother (2005) 49:269-75. doi:10.1128/AAC.49.1.269-275.2005

48. Wilde CG, Griffith JE, Marra MN, Snable JL, Scott RW. Purification and characterization of human neutrophil peptide 4, a novel member of the defensin family. J Biol Chem (1989) 264:11200-3.

49. Jones DE, Bevins CL. Paneth cells of the human small intestine express an antimicrobial peptide gene. J Biol Chem (1992) 267:23216-25.

50. Schroeder B, Ehmann D, Precht J, Castillo P, Küchler R, Berger J, et al. Paneth cell $\alpha$-defensin 6 (HD-6) is an antimicrobial peptide. Mucosal Immunol (2015) 8:661-71. doi:10.1038/mi.2014.100

51. Lombardi L, Maisetta G, Batoni G, Tavanti A. Insights into the antimicrobial properties of hepcidins: advantages and drawbacks as potential therapeutic agents. Molecules (2015) 20:6319-41. doi:10.3390/molecules20046319

52. Scott A, Weldon S, Taggart CC. SLPI and elafin: multifunctional antiproteases of the WFDC family. Biochem Soc Trans (2011) 39:1437-40. doi:10.1042/ BST0391437

53. Avdeeva SV, Chernukha MU, Shaginyan IA, Tarantul VZ, Naroditsky BS. Human angiogenin lacks specific antimicrobial activity. Curr Microbiol (2006) 53:477-8. doi:10.1007/s00284-006-0033-6

54. Yang D, Chen Q, Hoover DM, Staley P, Tucker KD, Lubkowski J, et al. Many chemokines including CCL20/MIP-3alpha display antimicrobial activity. J Leukoc Biol (2003) 74:448-55. doi:10.1189/jlb.0103024

55. Söbirk SK, Mörgelin M, Egesten A, Bates P, Shannon O, Collin M. Human chemokines as antimicrobial peptides with direct parasiticidal effect on Leishmania mexicana in vitro. PLoS One (2013) 8:e58129. doi:10.1371/ journal.pone.0058129

56. Hieshima K, Ohtani H, Shibano M, Izawa D, Nakayama T, Kawasaki Y, et al. CCL28 has dual roles in mucosal immunity as a chemokine with broadspectrum antimicrobial activity. J Immunol (2003) 170:1452-61. doi:10.4049/ jimmunol.170.3.1452

57. Cole AM, Ganz T, Liese AM, Burdick MD, Liu L, Strieter RM. Cutting edge: IFN-inducible ELR-CXC chemokines display defensin-like antimicrobial activity. J Immunol (2001) 167:623-7. doi:10.4049/jimmunol.167.2.623

58. Mattar EH, Almehdar HA, Yacoub HA, Uversky VN, Redwan EM. Antimicrobial potentials and structural disorder of human and animal defensins. Cytokine Growth Factor Rev (2016) 28:95-111. doi:10.1016/j. cytogfr.2015.11.002

59. Jensen-Jarolim E, Pacios LF, Bianchini R, Hofstetter G, Roth-Walter F. Structural similarities of human and mammalian lipocalins, and their function in innate immunity and allergy. Allergy (2016) 71:286-94. doi:10.1111/ all.12797
60. Bundgaard JR, Sengeløv H, Borregaard N, Kjeldsen L. Molecular cloning and expression of a cDNA encoding NGAL: a lipocalin expressed in human neutrophils. Biochem Biophys Res Commun (1994) 202:1468-75. doi:10.1006/ bbrc. 1994.2096

61. Friedl A, Stoesz SP, Buckley P, Gould MN. Neutrophil gelatinase-associated lipocalin in normal and neoplastic human tissues. Cell type-specific pattern of expression. Histochem J (1999) 31:433-41. doi:10.1023/A:1003708808934

62. Meheus LA, Fransen LM, Raymackers JG, Blockx HA, Van Beeumen JJ, Van Bun SM, et al. Identification by microsequencing of lipopolysaccharide-induced proteins secreted by mouse macrophages. J Immunol (1993) 151:1535-47.

63. Vizzardelli C, Pavelka N, Luchini A, Zanoni I, Bendickson L, Pelizzola M, et al. Effects of dexamethazone on LPS-induced activation and migration of mouse dendritic cells revealed by a genome-wide transcriptional analysis. Eur J Immunol (2006) 36:1504-15. doi:10.1002/eji.200535488

64. Cash HL, Whitham CV, Behrendt CL, Hooper LV. Symbiotic bacteria direct expression of an intestinal bactericidal lectin. Science (2006) 313:1126-30. doi:10.1126/science.1127119

65. Torrent M, Badia M, Moussaoui M, Sanchez D, Nogués MV, Boix E. Comparison of human RNase 3 and RNase 7 bactericidal action at the Gramnegative and Gram-positive bacterial cell wall. FEBS J (2010) 277:1713-25. doi:10.1111/j.1742-4658.2010.07595.x

66. Frew L, Stock SJ. Antimicrobial peptides and pregnancy. Reproduction (2011) 141:725-35. doi:10.1530/REP-10-0537

67. Zanetti M. Cathelicidins, multifunctional peptides of the innate immunity. J Leukoc Biol (2004) 75:39-48. doi:10.1189/jlb.0403147

68. Bals R, Weiner DJ, Moscioni AD, Meegalla RL, Wilson JM. Augmentation of innate host defense by expression of a cathelicidin antimicrobial peptide. Infect Immun (1999) 67:6084-9.

69. Schneider JJ, Unholzer A, Schaller M, Schäfer-Korting M, Korting HC. Human defensins. J Mol Med (Berl) (2005) 83:587-95. doi:10.1007/ s00109-005-0657-1

70. Ganz T. Iron in innate immunity: starve the invaders. Curr Opin Immunol (2009) 21:63-7. doi:10.1016/j.coi.2009.01.011

71. Michels K, Nemeth E, Ganz T, Mehrad B. Hepcidin and host defense against infectious diseases. PLoS Pathog (2015) 11:e1004998. doi:10.1371/journal. ppat.1004998

72. Goetz DH, Holmes MA, Borregaard N, Bluhm ME, Raymond KN, Strong RK. The neutrophil lipocalin NGAL is a bacteriostatic agent that interferes with siderophore-mediated iron acquisition. Mol Cell (2002) 10:1033-43. doi:10.1016/S1097-2765(02)00708-6

73. Kolls JK, McCray PB, Chan YR. Cytokine-mediated regulation of antimicrobial proteins. Nat Rev Immunol (2008) 8:829-35. doi:10.1038/nri2433

74. Flower DR. The lipocalin protein family: structure and function. Biochem J (1996) 318(Pt 1):1-14. doi:10.1042/bj3180001

75. Pinheiro Da Silva F, MacHado MCC. Antimicrobial peptides: clinical relevance and therapeutic implications. Peptides (2012) 36:308-14. doi:10.1016/j. peptides.2012.05.014

76. Doss M, White MR, Tecle T, Hartshorn KL. Human defensins and LL-37 in mucosal immunity. J Leukoc Biol (2010) 87:79-92. doi:10.1189/jlb.0609382

77. Sun C-L, Zhang F-Z, Li P, Bi L-Q. LL-37 expression in the skin in systemiclupus erythematosus. Lupus (2011) 20:904-11. doi:10.1177/0961203311398515

78. Lecaille F, Lalmanach G, Andrault PM. Antimicrobial proteins and peptides in human lung diseases: a friend and foe partnership with host proteases. Biochimie (2016) 122:151-68. doi:10.1016/j.biochi.2015.08.014

79. Hiemstra PS, Amatngalim GD, Van Der Does AM, Taube C. Antimicrobial peptides and innate lung defenses: role in infectious and noninfectious lung diseases and therapeutic applications. Chest (2016) 149:545-51. doi:10.1378/ chest.15-1353

80. Xiao W, Hsu Y-P, Ishizaka A, Kirikae T, Moss RB. Sputum cathelicidin, urokinase plasminogen activation system components, and cytokines discriminate cystic fibrosis, COPD, and asthma inflammation. Chest (2005) 128:2316-26. doi:10.1378/chest.128.4.2316

81. Heilborn JD, Nilsson MF, Kratz G, Weber G, Sørensen O, Borregaard N, et al. The cathelicidin anti-microbial peptide LL-37 is involved in re-epithelialization of human skin wounds and is lacking in chronic ulcer epithelium. J Invest Dermatol (2003) 120:379-89. doi:10.1046/j.1523-1747.2003.12069.x 
82. Ong PY, Ohtake T, Brandt C, Strickland I, Boguniewicz M, Ganz T, et al. Endogenous antimicrobial peptides and skin infections in atopic dermatitis. N Engl J Med (2002) 347:1151-60. doi:10.1056/NEJMoa021481

83. Schauber J, Dorschner RA, Yamasaki K, Brouha B, Gallo RL. Control of the innate epithelial antimicrobial response is cell-type specific and dependent on relevant microenvironmental stimuli. Immunology (2006) 118:509-19. doi:10.1111/j.1365-2567.2006.02399.x

84. Peric M, Koglin S, Kim S-M, Morizane S, Besch R, Prinz JC, et al. IL-17A enhances vitamin D3-induced expression of cathelicidin antimicrobial peptide in human keratinocytes. J Immunol (2008) 181:8504-12. doi:10.4049/ jimmunol.181.12.8504

85. Becker MN, Diamond G, Verghese MW, Randell SH. CD14-dependent lipopolysaccharide-induced beta-defensin-2 expression in human tracheobronchial epithelium. J Biol Chem (2000) 275:29731-6. doi:10.1074/jbc. M000184200

86. Armitage AE, Eddowes LA, Gileadi U, Cole S, Spottiswoode N, Selvakumar TA, et al. Hepcidin regulation by innate immune and infectious stimuli. Blood (2011) 118:4129-39. doi:10.1182/blood-2011-04-351957

87. Chung B, Verdier F, Matak P, Deschemin J-C, Mayeux P, Vaulont S. Oncostatin $\mathrm{M}$ is a potent inducer of hepcidin, the iron regulatory hormone. FASEB J (2010) 24:2093-103. doi:10.1096/fj.09-152561

88. Malyszko J, Tesar V, MacDougall IC. Neutrophil gelatinase-associated lipocalin and hepcidin: what do they have in common and is there a potential interaction? Kidney Blood Press Res (2010) 33:157-65. doi:10.1159/000315436

89. Kim BJ, Rho YK, Lee HI, Jeong MS, Li K, Seo SJ, et al. The effect of calcipotriol on the expression of human beta defensin-2 and LL-37 in cultured human keratinocytes. Clin Dev Immunol (2009) 2009:645898. doi:10.1155/2009/645898

90. Koeffler HP, Reichel H, Bishop JE, Norman AW. gamma-Interferon stimulates production of 1,25-dihydroxyvitamin D3 by normal human macrophages. Biochem Biophys Res Commun (1985) 127:596-603. doi:10.1016/ S0006-291X(85)80202-3

91. Harder J, Meyer-Hoffert U, Teran LM, Schwichtenberg L, Bartels J, Maune $\mathrm{S}$, et al. Mucoid Pseudomonas aeruginosa, TNF-alpha, and IL-1beta, but not IL-6, induce human beta-defensin-2 in respiratory epithelia. Am J Respir Cell Mol Biol (2000) 22:714-21. doi:10.1165/ajrcmb.22.6.4023

92. Besson-Fournier C, Latour C, Kautz L, Bertrand J, Ganz T, Roth M-P, et al. Induction of activin $\mathrm{B}$ by inflammatory stimuli up-regulates expression of the iron-regulatory peptide hepcidin through Smad1/5/8 signaling. Blood (2012) 120:431-9. doi:10.1182/blood-2012-02-411470

93. Park K, Elias PM, Oda Y, Mackenzie D, Mauro T, Holleran WM, et al. Regulation of cathelicidin antimicrobial peptide expression by an endoplasmic reticulum (ER) stress signaling, vitamin D receptor-independent pathway. J Biol Chem (2011) 286:34121-30. doi:10.1074/jbc.M111.250431

94. Wang X, Zhang Z, Louboutin J-P, Moser C, Weiner DJ, Wilson JM. Airway epithelia regulate expression of human beta-defensin 2 through toll-like receptor 2. FASEB J (2003) 17:1727-9. doi:10.1096/fj.02-0616fje

95. Birchler T, Seibl R, Büchner K, Loeliger S, Seger R, Hossle JP, et al. Human tolllike receptor 2 mediates induction of the antimicrobial peptide human betadefensin2 in responsetobacteriallipoprotein. EurJ Immunol(2001)31:3131-7. doi:10.1002/1521-4141(200111)31:11<3131::AID-IMMU3131>3.0.CO;2-G

96. Piperno A, Mariani R, Trombini P, Girelli D. Hepcidin modulation in human diseases: from research to clinic. World J Gastroenterol (2009) 15:538-51. doi:10.3748/wjg.15.538

97. Dittrich AM, Krokowski M, Meyer H-A, Quarcoo D, Avagyan A, Ahrens B, et al. Lipocalin2 protects against airway inflammation and hyperresponsiveness in a murine model of allergic airway disease. Clin Exp Allergy (2010) 40:1689-700. doi:10.1111/j.1365-2222.2010.03508.x

98. Cowland JB, Sørensen OE, Sehested M, Borregaard N. Neutrophil gelatinase-associated lipocalin is up-regulated in human epithelial cells by IL-1 beta, but not by TNF-alpha. J Immunol (2003) 171:6630-9. doi:10.4049/ jimmunol.171.12.6630

99. Aujla SJ, Chan YR, Zheng M, Fei M, Askew DJ, Pociask DA, et al. IL-22 mediates mucosal host defense against Gram-negative bacterial pneumonia. Nat Med (2008) 14:275-81. doi:10.1038/nm1710

100. Karlsen JR, Borregaard N, Cowland JB. Induction of neutrophil gelatinaseassociated lipocalin expression by co-stimulation with interleukin-17 and tumor necrosis factor-alpha is controlled by IkappaB-zeta but neither by C/
EBP-beta nor C/EBP-delta. J Biol Chem (2010) 285:14088-100. doi:10.1074/ jbc.M109.017129

101. Orabona C, Dumoutier L, Renauld JC. Interleukin-9 induces 24P3 lipocalin gene expression in murine T cell lymphomas. Eur Cytokine Netw (2001) 12:154-61.

102. Bu D, Hemdahl A-L, Gabrielsen A, Fuxe J, Zhu C, Eriksson P, et al. Induction of neutrophil gelatinase-associated lipocalin in vascular injury via activation of nuclear factor-kappaB. Am J Pathol (2006) 169:2245-53. doi:10.2353/ ajpath.2006.050706

103. Bando M, Hiroshima Y, Kataoka M, Shinohara Y, Herzberg MC, Ross KF, et al. Interleukin-1alpha regulates antimicrobial peptide expression in human keratinocytes. Immunol Cell Biol (2007) 85:532-7. doi:10.1038/sj.icb.7100078

104. Raffatellu M, George MD, Akiyama Y, Hornsby MJ, Nuccio S-P, Paixao TA, et al. Lipocalin-2 resistance confers an advantage to Salmonella enterica serotype typhimurium for growth and survival in the inflamed intestine. Cell Host Microbe (2009) 5:476-86. doi:10.1016/j.chom.2009.03.011

105. Kida Y, Shimizu T, Kuwano K. Sodium butyrate up-regulates cathelicidin gene expression via activator protein-1 and histone acetylation at the promoter region in a human lung epithelial cell line, EBC-1. Mol Immunol (2006) 43:1972-81. doi:10.1016/j.molimm.2005.11.014

106. Steinmann J, Halldórsson S, Agerberth B, Gudmundsson GH. Phenylbutyrate induces antimicrobial peptide expression. Antimicrob Agents Chemother (2009) 53:5127-33. doi:10.1128/AAC.00818-09

107. Sarker P, Ahmed S, Tiash S, Rekha RS, Stromberg R, Andersson J, et al. Phenylbutyrate counteracts Shigella mediated downregulation of cathelicidin in rabbit lung and intestinal epithelia: a potential therapeutic strategy. PLoS One (2011) 6:e20637. doi:10.1371/journal.pone.0020637

108. Sørensen OE, Cowland JB, Theilgaard-Mönch K, Liu L, Ganz T, Borregaard $\mathrm{N}$. Wound healing and expression of antimicrobial peptides/polypeptides in human keratinocytes, a consequence of common growth factors. J Immunol (2003) 170:5583-9. doi:10.4049/jimmunol.170.11.5583

109. Liu PT, Stenger S, Li H, Wenzel L, Tan BH, Krutzik SR, et al. Toll-like receptor triggering of a vitamin D-mediated human antimicrobial response. Science (2006) 311:1770-3. doi:10.1126/science.1123933

110. Nell MJ, Tjabringa GS, Vonk MJ, Hiemstra PS, Grote JJ. Bacterial products increase expression of the human cathelicidin hCAP-18/LL-37 in cultured human sinus epithelial cells. FEMS Immunol Med Microbiol (2004) 42:225-31. doi:10.1016/j.femsim.2004.05.013

111. Termén S, Tollin M, Rodriguez E, Sveinsdóttir SH, Jóhannesson B, Cederlund A, et al. PU.1 and bacterial metabolites regulate the human gene CAMP encoding antimicrobial peptide LL-37 in colon epithelial cells. Mol Immunol (2008) 45:3947-55. doi:10.1016/j.molimm.2008.06.020

112. Gombart AF. The vitamin D-antimicrobial peptide pathway and its role in protection against infection. Future Microbiol (2009) 4:1151-65. doi:10.2217/ fmb.09.87

113. Lu Z, Kim KA, Suico MA, Li JD, Kai H. MEF up-regulates human betadefensin 2 expression in epithelial cells. FEBS Lett (2004) 561(1-3):117-21. doi:10.1016/S0014-5793(04)00138-3

114. Zhen AW, Nguyen NH, Gibert Y, Motola S, Buckett P, Wessling-Resnick M, et al. The small molecule, genistein, increases hepcidin expression in human hepatocytes. Hepatology (2013) 58:1315-25. doi:10.1002/hep.26490

115. Kjeldsen L, Cowland JB, Borregaard N. Human neutrophil gelatinaseassociated lipocalin and homologous proteins in rat and mouse. Biochim Biophys Acta (2000) 1482:272-83. doi:10.1016/S0167-4838(00)00152-7

116. Bratt T. Lipocalins and cancer. Biochim Biophys Acta (2000) 1482:318-26. doi:10.1016/S0167-4838(00)00154-0

117. Griffin S, Taggart CC, Greene CM, O’Neill S, McElvaney NG. Neutrophil elastase up-regulates human beta-defensin-2 expression in human bronchial epithelial cells. FEBS Lett (2003) 546:233-6. doi:10.1016/ S0014-5793(03)00577-5

118. Corradini E, Schmidt PJ, Meynard D, Garuti C, Montosi G, Chen S, et al. BMP6 treatment compensates for the molecular defect and ameliorates hemochromatosis in Hfe knockout mice. Gastroenterology (2010) 139:17219. doi:10.1053/j.gastro.2010.07.044

119. Nelson AM, Zhao W, Gilliland KL, Zaenglein AL, Liu W, Thiboutot DM. Neutrophil gelatinase-associated lipocalin mediates 13 -cis retinoic acid-induced apoptosis of human sebaceous gland cells. J Clin Invest (2008) 118:1468-78. doi:10.1172/JCI33869 
120. Caramuta S, De Cecco L, Reid JF, Zannini L, Gariboldi M, Kjeldsen L, et al. Regulation of lipocalin-2 gene by the cancer chemopreventive retinoid 4-HPR. Int J Cancer (2006) 119:1599-606. doi:10.1002/ijc.22030

121. Jiang W, Sunkara LT, Zeng X, Deng Z, Myers SM, Zhang G. Differential regulation of human cathelicidin LL-37 by free fatty acids and their analogs. Peptides (2013) 50:129-38. doi:10.1016/j.peptides.2013.10.008

122. Talukder P, Satho T, Irie K, Sharmin T, Hamady D, Nakashima Y, et al. Trace metal zinc stimulates secretion of antimicrobial peptide LL-37 from Caco-2 cells through ERK and p38 MAP kinase. Int Immunopharmacol (2011) 11:141-4. doi:10.1016/j.intimp.2010.10.010

123. Cederlund A, Kai-Larsen Y, Printz G, Yoshio H, Alvelius G, Lagercrantz $\mathrm{H}$, et al. Lactose in human breast milk an inducer of innate immunity with implications for a role in intestinal homeostasis. PLoS One (2013) 8:e53876. doi:10.1371/journal.pone.0053876

124. Tomita T, Nagase T, Ohga E, Yamaguchi Y, Yoshizumi M, Ouchi Y. Molecular mechanisms underlying human beta-defensin-2 gene expression in a human airway cell line (LC2/ad). Respirology (2002) 7:305-10. doi:10.1046/j.1440-1843.2002.00415.x

125. Guo S, Casu C, Gardenghi S, Booten S, Aghajan M, Peralta R, et al. Reducing TMPRSS6 ameliorates hemochromatosis and $\beta$-thalassemia in mice. J Clin Invest (2013) 123:1531-41. doi:10.1172/JCI66969

126. TONG Z, WU X, KEHRER JP. Increased expression of the lipocalin $24 \mathrm{p} 3$ as an apoptotic mechanism for MK886. Biochem $J$ (2003) 372:203-10. doi:10.1042/bj20021696

127. Tong Z, Wu X, Ovcharenko D, Zhu J, Chen C-S, Kehrer JP. Neutrophil gelatinase-associated lipocalin as a survival factor. Biochem J (2005) 391:441-8. doi:10.1042/BJ20051020

128. Méndez-Samperio P, Miranda E, Trejo A. Expression and secretion of cathelicidin LL-37 in human epithelial cells after infection by Mycobacterium bovis Bacillus Calmette-Guérin. Clin Vaccine Immunol (2008) 15:1450-5. doi:10.1128/CVI.00178-08

129. Chakraborty K, Ghosh S, Koley H, Mukhopadhyay AK, Ramamurthy T, Saha DR, et al. Bacterial exotoxins downregulate cathelicidin (hCAP-18/LL-37) and human beta-defensin 1 (HBD-1) expression in the intestinal epithelial cells. Cell Microbiol (2008) 10:2520-37. doi:10.1111/j.1462-5822.2008.01227.x

130. Islam D, Bandholtz L, Nilsson J, Wigzell H, Christensson B, Agerberth B, et al. Downregulation of bactericidal peptides in enteric infections: a novel immune escape mechanism with bacterial DNA as a potential regulator. Nat Med (2001) 7:180-5. doi:10.1038/84627

131. Bergman P, Johansson L, Asp V, Plant L, Gudmundsson GH, Jonsson $\mathrm{A}-\mathrm{B}$, et al. Neisseria gonorrhoeae downregulates expression of the human antimicrobial peptide LL-37. Cell Microbiol (2005) 7:1009-17. doi:10.1111/j.1462-5822.2005.00530.x

132. Poli M, Asperti M, Ruzzenenti P, Regoni M, Arosio P. Hepcidin antagonists for potential treatments of disorders with hepcidin excess. Front Pharmacol (2014) 5:86. doi:10.3389/fphar.2014.00086

133. Poli M, Girelli D, Campostrini N, Maccarinelli F, Finazzi D, Luscieti S, et al. Heparin: a potent inhibitor of hepcidin expression in vitro and in vivo. Blood (2011) 117:997-1004. doi:10.1182/blood-2010-06-289082

134. Song S-NJ, Tomosugi N, Kawabata H, Ishikawa T, Nishikawa T, Yoshizaki K. Down-regulation of hepcidin resulting from long-term treatment with an anti-IL-6 receptor antibody (tocilizumab) improves anemia of inflammation in multicentric Castleman disease. Blood (2010) 116:3627-34. doi:10.1182/ blood-2010-03-271791

135. Zhang S-P, Wang Z, Wang L-X, Liu S-J. AG490: an inhibitor of hepcidin expression in vivo. World J Gastroenterol (2011) 17:5032-4. doi:10.3748/wjg. v17.i45.5032

136. Doyle MK, Rahman MU, Frederick B, Birbara CA, de Vries D, Toedter G, et al. Effects of subcutaneous and intravenous golimumab on inflammatory biomarkers in patients with rheumatoid arthritis: results of a phase 1, randomized, open-label trial. Rheumatology (Oxford) (2013) 52:1214-9. doi:10.1093/rheumatology/kes381

137. Sadar S, Kaspate D, Vyawahare N. Protective effect of L-glutamine against diabetes-induced nephropathy in experimental animal: role of KIM-1, NGAL, TGF- $\beta 1$, and collagen-1. Ren Fail (2016) 38:1483-95. doi:10.1080/ 0886022X.2016.1227918

138. Song B, Zhang H, Jiang L, Chi Y, Tian J, Du W, et al. Down-regulation of lipocalin 2 suppresses the growth of human lung adenocarcinoma through oxidative stress involving Nrf2/HO-1 signaling. Acta Biochim Biophys Sin (Shanghai) (2015) 47:805-14. doi:10.1093/abbs/gmv085

139. Agerberth B, Charo J, Werr J, Olsson B, Idali F, Lindbom L, et al. The human antimicrobial and chemotactic peptides LL-37 and alpha-defensins are expressed by specific lymphocyte and monocyte populations. Blood (2000) 96:3086-93.

140. Fung E, Nemeth E. Manipulation of the hepcidin pathway for therapeutic purposes. Haematologica (2013) 98:1667-76. doi:10.3324/haematol.2013.084624

141. Lucisano S, Arena A, Stassi G, Iannello D, Montalto G, Romeo A, et al. Role of paricalcitol in modulating the immune response in patients with renal disease. Int J Endocrinol (2015) 2015:1-8. doi:10.1155/2015/765364

142. Aberg KM, Radek KA, Choi E-H, Kim D-K, Demerjian M, Hupe M, et al. Psychological stress downregulates epidermal antimicrobial peptide expression and increases severity of cutaneous infections in mice. J Clin Invest (2007) 117:3339-49. doi:10.1172/JCI31726

143. Williams MR, Sakurai Y, Zughaier SM, Eskin SG, McIntire LV. Transmigration across activated endothelium induces transcriptional changes, inhibits apoptosis, and decreases antimicrobial protein expression in human monocytes. J Leukoc Biol (2009) 86:1331-43. doi:10.1189/jlb.0209062

144. Lee YC, Tzeng W-F, Chiou T-J, Chu ST. MicroRNA-138 suppresses neutrophil gelatinase-associated lipocalin expression and inhibits tumorigenicity. PLoS One (2012) 7:e52979. doi:10.1371/journal.pone.0052979

145. Tong Z, Chakraborty S, Sung B, Koolwal P, Kaur S, Aggarwal BB, et al. Epidermal growth factor down-regulates the expression of neutrophil gelatinase-associated lipocalin (NGAL) through E-cadherin in pancreatic cancer cells. Cancer (2011) 117:2408-18. doi:10.1002/cncr.25803

146. Duits LA, Nibbering PH, van Strijen E, Vos JB, Mannesse-Lazeroms SPG, van Sterkenburg MAJA, et al. Rhinovirus increases human beta-defensin-2 and -3 mRNA expression in cultured bronchial epithelial cells. FEMS Immunol Med Microbiol (2003) 38:59-64. doi:10.1016/S0928-8244(03)00106-8

147. Park CH, Valore EV, Waring AJ, Ganz T. Hepcidin, a urinary antimicrobial peptide synthesized in the liver. J Biol Chem (2001) 276:7806-10. doi:10.1074/ jbc.M008922200

148. Krause A, Neitz S, Mägert HJ, Schulz A, Forssmann WG, Schulz-Knappe $\mathrm{P}$, et al. LEAP-1, a novel highly disulfide-bonded human peptide, exhibits antimicrobial activity. FEBS Lett (2000) 480:147-50. doi:10.1016/ S0014-5793(00)01920-7

149. Krause A, Sillard R, Kleemeier B, Klüver E, Maronde E, Conejo-García JR, et al. Isolation and biochemical characterization of LEAP-2, a novel blood peptide expressed in the liver. Protein Sci (2003) 12:143-52. doi:10.1110/ ps.0213603

150. Meynard D, Kautz L, Darnaud V, Canonne-Hergaux F, Coppin H, Roth M-P. Lack of the bone morphogenetic protein BMP6 induces massive iron overload. Nat Genet (2009) 41:478-81. doi:10.1038/ng.320

151. Verga Falzacappa MV, Vujic Spasic M, Kessler R, Stolte J, Hentze MW, Muckenthaler MU. STAT3 mediates hepatic hepcidin expression and its inflammatory stimulation. Blood (2007) 109:353-8. doi:10.1182/ blood-2006-07-033969

152. Maisetta G, Petruzzelli R, Brancatisano FL, Esin S, Vitali A, Campa M, et al. Antimicrobial activity of human hepcidin 20 and 25 against clinically relevant bacterial strains: effect of copper and acidic pH. Peptides (2010) 31:1995-2002. doi:10.1016/j.peptides.2010.08.007

153. Borregaard N, Cowland JB. Neutrophil gelatinase-associated lipocalin, a siderophore-binding eukaryotic protein. Biometals (2006) 19(2):211-5. doi:10.1007/s10534-005-3251-7

154. Dittrich AM, Meyer HA, Hamelmann E. The role of lipocalins in airway disease. Clin Exp Allergy (2013) 43:503-11. doi:10.1111/cea.12025

155. Berger T, Togawa A, Duncan GS, Elia AJ, You-Ten A, Wakeham A, et al. Lipocalin 2-deficient mice exhibit increased sensitivity to Escherichia coli infection but not to ischemia-reperfusion injury. Proc Natl Acad Sci U S A (2006) 103:1834-9. doi:10.1073/pnas.0510847103

156. Flo TH, Smith KD, Sato S, Rodriguez DJ, Holmes MA, Strong RK, et al. Lipocalin 2 mediates an innate immune response to bacterial infection by sequestrating iron. Nature (2004) 432:917-21. doi:10.1038/nature03104

157. Abergel RJ, Wilson MK, Arceneaux JEL, Hoette TM, Strong RK, Byers $\mathrm{BR}$, et al. Anthrax pathogen evades the mammalian immune system through stealth siderophore production. Proc Natl Acad Sci U S A (2006) 103:18499-503. doi:10.1073/pnas.0607055103 
158. Holmes MA, Paulsene W, Jide X, Ratledge C, Strong RK. Siderocalin (Lcn 2) also binds carboxymycobactins, potentially defending against mycobacterial infections through iron sequestration. Structure (2005) 13:29-41. doi:10.1016/j.str.2004.10.009

159. Puthumana J, Ariza X, Belcher JM, Graupera I, Ginès P, Parikh CR. Urine interleukin 18 and lipocalin 2 are biomarkers of acute tubular necrosis in patients with cirrhosis: a systematic review and meta-analysis. Clin Gastroenterol Hepatol (2016). doi:10.1016/j.cgh.2016.11.035

160. Schmidt-Ott KM, Mori K, Kalandadze A, Li J-Y, Paragas N, Nicholas T, et al. Neutrophil gelatinase-associated lipocalin-mediated iron traffic in kidney epithelia. Curr Opin Nephrol Hypertens (2006) 15:442-9. doi:10.1097/01. mnh.0000232886.81142.58

161. Becknell B, Schwaderer A, Hains DS, Spencer JD. Amplifying renal immunity: the role of antimicrobial peptides in pyelonephritis. Nat Rev Nephrol (2015) 11:642-55. doi:10.1038/nrneph.2015.105

162. Jain V, Mehta Y, Gupta A, Sharma R, Raizada A, Trehan N. The role of neutrophil gelatinase-associated lipocalin in predicting acute kidney injury in patients undergoing off-pump coronary artery bypass graft: a pilot study. Ann Card Anaesth (2016) 19:225. doi:10.4103/0971-9784.179590

163. Zhang A, Cai Y, Wang P-F, Qu J-N, Luo Z-C, Chen X-D, et al. Diagnosis and prognosis of neutrophil gelatinase-associated lipocalin for acute kidney injury with sepsis: a systematic review and meta-analysis. Crit Care (2016) 20:41. doi:10.1186/s13054-016-1212-x

164. Ariza X, Graupera I, Coll M, Solà E, Barreto R, García E, et al. Neutrophil gelatinase-associated lipocalin is a biomarker of acute-on-chronic liver failure and prognosis in cirrhosis. J Hepatol (2016) 65:57-65. doi:10.1016/j. jhep.2016.03.002

165. Balan A, Lucchini G, Schmidt S, Schneider A, Tramsen L, Kuc S, et al. Mesenchymal stromal cells in the antimicrobial host response of hematopoietic stem cell recipients with graft-versus-host disease - friends or foes? Leukemia (2014) 28:1941-8. doi:10.1038/leu.2014.127

166. Roemeling-van Rhijn M, Mensah FKF, Korevaar SS, Leijs MJ, van Osch GJVM, Ijzermans JNM, et al. Effects of hypoxia on the immunomodulatory properties of adipose tissue-derived mesenchymal stem cells. Front Immunol (2013) 4:203. doi:10.3389/fimmu.2013.00203

167. Lopez-Verrilli MA, Caviedes A, Cabrera A, Sandoval S, Wyneken U, Khoury M. Mesenchymal stem cell-derived exosomes from different sources selectively promote neuritic outgrowth. Neuroscience (2016) 320:129-39. doi:10.1016/j.neuroscience.2016.01.061

168. Alcayaga-Miranda F, González PL, Lopez-Verrilli A, Varas-Godoy M, AguilaDíaz C, Contreras L, et al. Prostate tumor-induced angiogenesis is blocked by exosomes derived from menstrual stem cells through the inhibition of reactive oxygen species. Oncotarget (2016) 7(28):44462-77. doi:10.18632/ oncotarget.9852

169. Hiemstra TF, Charles PD, Gracia T, Hester SS, Gatto L, Al-Lamki R, et al. Human urinary exosomes as innate immune effectors. J Am Soc Nephrol (2014) 25(9):2017-27. doi:10.1681/ASN.2013101066

170. Lässer C, O’Neil SE, Shelke GV, Sihlbom C, Hansson SF, Gho YS, et al. Exosomes in the nose induce immune cell trafficking and harbour an altered protein cargo in chronic airway inflammation. J Transl Med (2016) 14:181. doi:10.1186/s12967-016-0927-4

171. Hu G, Gong A-Y, Roth AL, Huang BQ, Ward HD, Zhu G, et al. Release of luminal exosomes contributes to TLR4-mediated epithelial antimicrobial defense. PLoS Pathog (2013) 9:e1003261. doi:10.1371/journal.ppat.1003261

172. Bruno S, Grange C, Deregibus MC, Calogero RA, Saviozzi S, Collino F, et al. Mesenchymal stem cell-derived microvesicles protect against acute tubular injury. J Am Soc Nephrol (2009) 20:1053-67. doi:10.1681/ ASN.2008070798

173. Shabbir A, Cox A, Rodriguez-Menocal L, Salgado M, Van Badiavas E. Mesenchymal stem cell exosomes induce proliferation and migration of normal and chronic wound fibroblasts, and enhance angiogenesis in vitro. Stem Cells Dev (2015) 24:1635-47. doi:10.1089/scd.2014.0316

174. Zhu Y-G, Feng X-M, Abbott J, Fang X-H, Hao Q, Monsel A, et al. Human mesenchymal stem cell microvesicles for treatment of Escherichia coli endotoxin-induced acute lung injury in mice. Stem Cells (2014) 32:116-25. doi:10.1002/stem.1504

175. Monsel A, Zhu Y, Gennai S, Hao Q, Hu S, Rouby J-J, et al. Therapeutic effects of human mesenchymal stem cell-derived microvesicles in severe pneumonia in mice. Am J Respir Crit Care Med (2015) 192:324-36. doi:10.1164/ rccm.201410-1765OC

176. Tang K, Zhang Y, Zhang H, Xu P, Liu J, Ma J, et al. Delivery of chemotherapeutic drugs in tumour cell-derived microparticles. Nat Commun (2012) 3:1282. doi: $10.1038 /$ ncomms 2282

177. Kim MS, Haney MJ, Zhao Y, Mahajan V, Deygen I, Klyachko NL, et al. Development of exosome-encapsulated paclitaxel to overcome MDR in cancer cells. Nanomedicine (2016) 12:655-64. doi:10.1016/j.nano.2015.10.012

178. Andersson DI, Hughes D, Kubicek-Sutherland JZ. Mechanisms and consequences of bacterial resistance to antimicrobial peptides. Drug Resist Updat (2016) 26:43-57. doi:10.1016/j.drup.2016.04.002

179. Wang T-T, Nestel FP, Bourdeau V, Nagai Y, Wang Q, Liao J, et al. Cutting edge: 1,25-dihydroxyvitamin D3 is a direct inducer of antimicrobial peptide gene expression. J Immunol (2004) 173:2909-12. doi:10.4049/jimmunol.173. 5.2909

180. Weber G, Heilborn JD, Chamorro Jimenez CI, Hammarsjo A, Törmä H, Stahle M. Vitamin D induces the antimicrobial protein hCAP18 in human skin. J Invest Dermatol (2005) 124:1080-2. doi:10.1111/j.0022-202X.2005.23687.x

181. Han JE, Jones JL, Tangpricha V, Brown MA, Hao L, Hebbar G, et al. High dose vitamin $\mathrm{D}$ administration in ventilated intensive care unit patients: a pilot double blind randomized controlled trial. J Clin Transl Endocrinol (2016) 4:59-65. doi:10.1016/j.jcte.2016.04.004

182. Posa F, Di Benedetto A, Colaianni G, Cavalcanti-Adam EA, Brunetti G, Porro C, et al. Vitamin D effects on osteoblastic differentiation of mesenchymal stem cells from dental tissues. Stem Cells Int (2016) 2016:9150819. doi: $10.1155 / 2016 / 9150819$

183. Theurl I, Schroll A, Sonnweber T, Nairz M, Theurl M, Willenbacher W, et al. Pharmacologic inhibition of hepcidin expression reverses anemia of chronic inflammation in rats. Blood (2011) 118:4977-84. doi:10.1182/ blood-2011-03-345066

184. Steinbicker AU, Sachidanandan C, Vonner AJ, Yusuf RZ, Deng DY, Lai CS, et al. Inhibition of bone morphogenetic protein signaling attenuates anemia associated with inflammation. Blood (2011) 117:4915-23. doi:10.1182/ blood-2010-10-313064

185. Sun CC, Vaja V, Chen S, Theurl I, Stepanek A, Brown DE, et al. A hepcidin lowering agent mobilizes iron for incorporation into red blood cells in an adenine-induced kidney disease model of anemia in rats. Nephrol Dial Transplant (2013) 28:1733-43. doi:10.1093/ndt/gfs584

186. Isis Pharmaceuticals, Inc. Xenon Licenses Antisense Drug XEN701 from Isis and Initiates Preclinical Toxicology Studies. (2013). Available at: http://www. prnewswire.com/news-releases/xenon-licenses-antisense-drug-xen701-fro $\mathrm{m}$-isis-and-initiates-preclinical-toxicology-studies-210801061.html

187. Fatih N, Camberlein E, Island ML, Corlu A, Abgueguen E, Détivaud L, et al. Natural and synthetic STAT3 inhibitors reduce hepcidin expression in differentiated mouse hepatocytes expressing the active phosphorylated STAT3 form. J Mol Med (Berl) (2010) 88:477-86. doi:10.1007/s00109-009-0588-3

Conflict of Interest Statement: MK is the chief science officer of Cells for Cells and Consorcio Regenero. FA-M and JC received stipends from Cells for Cells.

The reviewers HG and FC and handling Editor declared their shared affiliation, and the handling Editor states that the process nevertheless met the standards of a fair and objective review.

Copyright (c) 2017 Alcayaga-Miranda, Cuenca and Khoury. This is an open-access article distributed under the terms of the Creative Commons Attribution License (CC $B Y)$. The use, distribution or reproduction in other forums is permitted, provided the original author(s) or licensor are credited and that the original publication in this journal is cited, in accordance with accepted academic practice. No use, distribution or reproduction is permitted which does not comply with these terms. 